\title{
CLEO/QELS'99報告
}

宅間 宏, 小林 孝嘉 $*$, 関川 太郎**, 玉木 裕介***, 西山 伸彦****, 吉村 政志 $* * * * *$, 平野 嘉仁 ${ }^{\dagger}$, 五神 真 ${ }^{\dagger \dagger}$, 上妻 幹男 ${ }^{\dagger \dagger}$, 鳥井 寿夫 $\dagger^{\dagger \dagger \dagger}$, 板谷太郎柎计

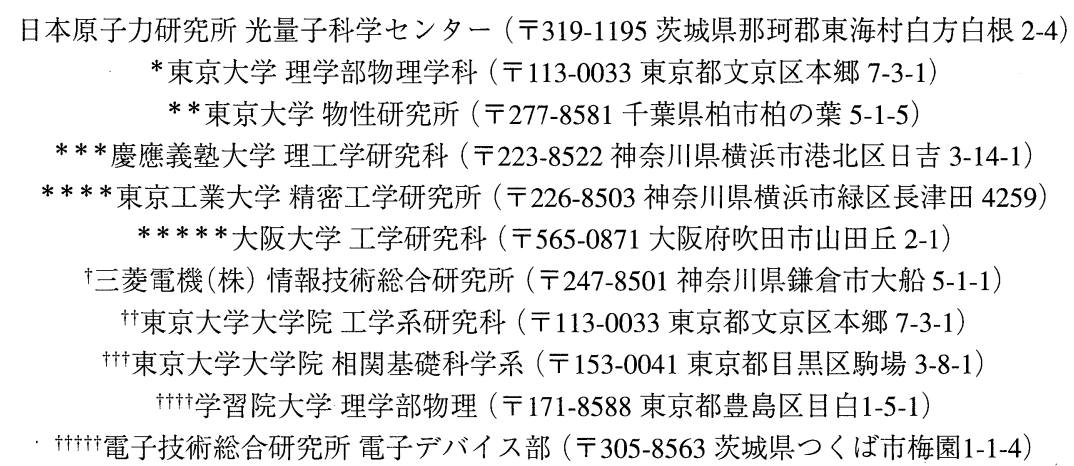

\section{Report on CLEO/QELS'99}

\author{
Hiroshi TAKUMA, Takayoshi KOBAYASHI,* Taro SEKIKAWA, ${ }^{* *}$ Yusuke TAMAKI,*** \\ Nobuhiko NISHIYAMA, ${ }^{* * * *}$ Masashi YOSHIMURA, ${ }^{* * * * *}$ Yoshihito HIRANO, ${ }^{\dagger}$ \\ Makoto GONOKAMI,,$^{\dagger \dagger}$ Mikio KOZUMA, ${ }^{\dagger \dagger \dagger}$ Yoshio TORII, ${ }^{\dagger \dagger \dagger \dagger}$ and Taro ITATANI ${ }^{\dagger \dagger \dagger \dagger \dagger}$ \\ Kansai Research Establishment, Japan Atomic Energy Research Institute \\ 2-4 Shirakata Shirane, Tokai-mura, Naka-gun, Ibaraki 319-1195 \\ *Department of Physics, Faculty of Science, University of Tokyo, 7-3-1 Hongo, Bunkyo-ku, Tokyo 113-0033 \\ ** Institute for Solid State Physics, University of Tokyo, 5-1-5 Kashiwanoha, Kashiwa, Chiba 277-8581 \\ *** Faculty of Electric Engineering Department of Science \& Technology, Keio University \\ 3-14-1 Hiyoshi, Kohoku-ku, Yokohama, Kanagawa 223-8522 \\ **** Precision and Intelligence Laboratory, Tokyo Institute of Technology \\ 4259 Nagatsuta, Midori-ku, Yokohama, Kanagawa 226-8503 \\ *****Department of Electrical Engineering, Osaka University, 2-1 Yamada-oka, Suita, Osaka 565-0871 \\ ${ }^{\dagger}$ Information Technology R\&D Center, Mitsubishi Electric Corporation, 5-1-1 Ofuna, Kamakura, Kanagawa 247-8501 \\ ${ }^{\dagger}$ Department of Applied Physics, School of Engineering, University of Tokyo, 7-3-1 Hongo, Bunkyo-ku, Tokyo 113-8656 \\ ${ }^{t \dagger}$ Institute of Physics, University of Tokyo, 3-8-1 Komaba, Meguro-ku, Tokyo 153-0041 \\ ${ }^{+1 t \dagger}$ Department of Physics, Gakushuin University, 1-5-1 Mejiro, Toshima-ku, Tokyo 171-8588 \\ ${ }^{+\dagger+t \dagger}$ Electron Devices Division, Electrotechnical Laboratory, 1-1-4 Umezono, Tsukuba, Ibaraki 305-8563
}

(Received July 5, 1999)

1.はじめに

今回のCLEO/QELSも極めて盛会で, 展示への参加者を含 めて 5,600 人以上の登録者を記録したとのことである。欧 米での光技術全般に対する期待は大きく,21世紀における 主要な産業技術の一つとして学会だけでなく産業界の関 心も非常に大きなものがある。これに比べるとわが国の 政府も産業界も今一つ光産業の重要性への認識が甘いよ うに感じられる。

最近の量子エレクトロニクスの流れの特徴としてレー
ザーの性能のいろいろな面での著しい進歩を先ず挙げる ことができるが, 今回のCLEOにもその特徵は明確に見ら れた，過去の量子エレクトロニクス技術の進歩は, ある段 階でレーザーの性能が進歩し,それに続いて新しい応用が 開かれるというパターンで展開されてきた.レーザー性 能の進歩は応用の可能性を高めるから当然とも言えるが, むしろ応用を意識してレーザー性能を追求する姿勢が必 要である。

二十世紀のレーザー技術は, レーザーの精密度を殆ど理 論的限界まで高めることに成功し, 各種の学術的応用をは 
じめ,計測, 通信, 情報などの技術分野で画期的な展開を見 せた。一方で加工から核融合に至る広汎なレーザーエネ ルギーの応用分野では,フォトンの価格が高価なためには かばかしい展開が見難かった．最近の傾向はレーザーの 小型化, 高輝度化, 高効率化に関しての進歩が著しく,21世 紀に向けてのレーザーエネルギー応用の大きな展開が期 待される。

先ず半導体レーザー励起の固体レーザーの性能の向上 が引き続き進んでいるのは重要な意義を持つ傾向であ る. 今回の大きな進展の中で, $\mathrm{Yb}$ ガラスファイバレーザー の高出力化に注目したい. Yb系レーザーは, エネルギー構 造からの当然の帰結として,

(高効率) $\rightarrow($ 低ポンピングレベルでの吸収が大きい) $\rightarrow$ (高 輝度ポンピングの必要性) $\rightarrow($ (フイバレーザーの優位性) という思考の流れが必然的に行われなければならない. Yb系に限らず, ファイバレーザーは, ポンピングの効率, 単 一モード出力化, 冷却などいろいろな点に扔いて有利なこ とは言うまでもなく,今回のCLEOでも活発なセッション が組まれた。

ファイバレーザーの重要性は, いち早く植田(電通大)ら によって指摘されてきたが, 日本国内の産業界での一般的 認識は欧米に比較して低かった。現在ファイバレーザー の研究は中心的課題の一つであり,Yb系レーザーはその一 例に過ざないが,欧米ではすでにかなりの高出力 (平均出力 100W級)の市販品が生まれている。

なお,今のところ一般の固体レーザーではまだNd系がや や優位性を保っているが,レーザーの構造的工夫と半導体 レーザーの高輝度化によって, 産業応用分野でのYb系レー ザーの一般的優位性が確立されるのも時間の問題と考え られる。

このような流れを見て強調したいのは,すべて理論的な 必然性にしたがって技術が進展していることである。技 術の展開についてスコープを描くとき,如何に基礎的な思 考と信念とが重要であるかを示す一例として肝に銘じた い.

超高強度場効果に関するセッションでは, ローレンス。 リバモア国立研究所の単発200TWUTi:sapphireレーザーが 注目された。 大型Ti:sapphire結晶を用い, 大型のガラス レーザーで励起することによって, 単発ながら照射強度の 最高記録 $\left(10^{21} \mathrm{~W} / \mathrm{cm}^{2}\right)$ を達成した点で大きな意義を持つ. またミシガン大学の相対論効果の検証は, 高強度光によっ て電子の運動による磁場の影響が大きくなることを定量 的に検証した点で見事であった。その他, 興味ある成果が 高強度場のセッションや超高速現象のセッションで発表 されたのは,この領域が最先端領域として発展を続けてい ることの反映と考えられる.

今後ますます重要性が高まると予想される半導体レー ザーでは, 今回も日本で突破口が開かれたブルー・グリー ン・レーザーについて,論文数は少ないが関心は極めて高 いものを感じた. 量子井戸構造などの人工的構造材料が 有効に利用される領域としても興味が持たれるところで ある。

一方, QELSでは, 97年にノーベル賞の対象となった中性
原子のレーザー冷却は,ボーズ・アインシュタイン凝縮系 (BEC)の時代に突入した感がある。世界各地でBECが実現 し, 見事な原子波の干渉実験の成果が示され, まさに「原子 レーザー」が実現したことを実感した。

さて, 最近のCLEO/QELSに出席して感じるのは, CLEO とQELSとの実質上の一体化である。QELS関倸のセッ ションにおける出席者数は減っていないし, 討論も相変わ らず活発ではあるが, 登録者の数を見る限りではCLEOが 増えてQELSは減る一方とのことである. 基礎と応用の一 体化はよいことで,この領域の円熟度を示すと考えてよか ろう。事実,CLEOのセッションの内容でQELSのセッショ ンとしても馴染むものは多い.ヨーロッパでは始めから 実質的に一体化している。この表面的な現象を見て, QELS 不要論が出たとすればとんでもない短絡的思考といわざ るを得ない。

基礎と応用との時間的ずれが急速に短くなった現在, 画 期的な応用の展開には基礎がますます重要であるし, 適切 な基礎研究課題の選択には応用に関するインサイトが不 可欠である。このことを研究者が認識し, 説得に努力する ことによって, 日本国内でも 21 世紀の産業技術に扔ける光 学技術の重要性が社会的認識を得られるのではないかと 思われる。

(宅間宏)

\section{2. 超高速現象}

超高速現象に関するセッションは10駒あり, CTuL, Ultrafast optoelectronics, CTuR, Ultrafast shaping and optimization, JTuC, Ultrafast chemistry, QtuJ, Ultrafast relaxation processes, CWL, Ultrafast material dynamics, CThC, Ultrafast laser material modulation, CThL, Ultrafast pulse generation I, CThR, Ultrafast pulse generation II, CFA, Ultrafast pulse characterization I, CFG, Ultrafast pulse characterization IIであっ た. 全体で150駒のセッションのうち $6 \%$ に相当する非常に 幅の広い重要な分野である。これまでの会議と比較して も発表全体の推移からみても, 最近特に進展していること が顕著であったといえる.さららにこれ以外のセッション やポストデッドラインバーパーのセッションでも, 超高速 現象関係の発表がかなりの数であった。各セッションで 発表が5, 6件あるので総数 50 ～60件もあり,パラレルセッ ションで同時に発表が行われたものもあり,全部を網羅す るのは不可能である。本稿では筆者が実際に講演を聴き 評価できたものについて以下に記すことにしたい。

新しい非線形光学のセッションのQMB5で昨年不幸にし て亡くなったMoscow大のKroteevのグループから,「光結晶 中での光パルス圧縮」の発表があった。これまでフォト ニック結晶を用いたパルス成形問題はピコ秒時間領域の 研究だけであったが,ゆっくり変化する崩絡関数(SVEA) が成立しないくらい短いフェムト秒パルスについて理論 的考察を行っている。 それによると, mm以下の幾何学的 厚さでパルス圧縮を行うことができる。

火曜日の午前後半のセッションCTuF “Few-optical-cycle pulse generation”に扔いて短パルス発生に関する興味深い 発表が沢山なされた。まず，MITのIppenのグループ 


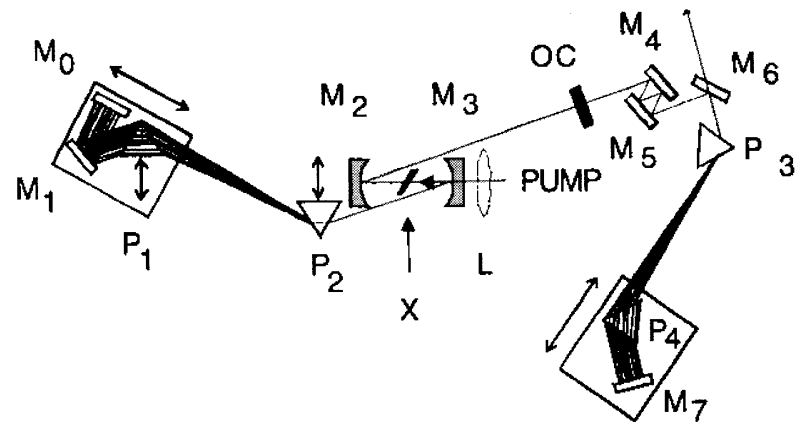

Fig.1 Laser setup: DCMs: $\mathrm{M}_{1}-\mathrm{M}_{6}$, silver mirrors $\mathrm{M}_{0}$ and $\mathrm{M}_{7}, \mathrm{CaF}_{2}$-prisms $\mathrm{P}_{1}, \mathrm{P}_{2}$, fused quartz prisms $\mathrm{P}_{3}, \mathrm{P}_{4}$. $\mathrm{X}$ : Ti:sapphire crystal, OC: output coupler, $\mathrm{L}: 10 \mathrm{~cm}$ lens. (CTuF1, F. X. Kürtner, et al.)

(CTuF1, 招待講演) から, Fig.1のような配置を用いて,レー ザー共振器から発生するパルスとしては,これまでで最も 短い5.5fsのパルスを繰り返し $100 \mathrm{MHz}$ で得ることができ た。このため, $400 \mathrm{~nm}$ 以上利得スペクトルバンド幅にわ たる $99.87 \%$ 以の高反射率の二重チャープ鏡を用いるこ とにより, 350nm以上の広いスペクトル領域の群速度分散 の補償を可能にした．更に，チャープ補償用に低分散の $\mathrm{CaF}_{2}$ プリズム対を用いて，これまでよりもより正確に チャープ補償ができた。この結果共振器から $\mathrm{sech}^{2}$ 波形を 仮定して, $5.5 \mathrm{fs}$ パルスが得られた。スペクトルのフーリエ 変換からは, 限界パルス幅は5.4fs となる(Fig.2). 白色干渉 の方法で群速度遅延は $2 \mathrm{fs}^{2}$ であった．既存の方法を採用し て非常に細かい設計をして共振器から最短パルスを得て いる。

次にSt. Andrews大のSibbettのグループ(CTuF2)は, Fig.3 に示すようなリング型共振器の自己モード同期レーザー を開発した。二次元安定解析領域の中央にデザインする ことができるので最大出力が得られる。また,パルスが共 振器の中の結晶を一回だけしか通過しないので, 結晶での 分散を最小にできる。ささに外部からフィードバックの 効果に対して強い. パルス伝搬の方向は, 可能な二方向の うち増幅結晶に入って直後に増幅される方向を選んだ. このレーザーからパルス幅13fs, パワースペクトル幅 $55 \mathrm{~nm}$ のパルスが得られ，従って時間バンド幅積 0.33 が得られ フーリエ限界に極めて近いパルス発生ができたことがわ

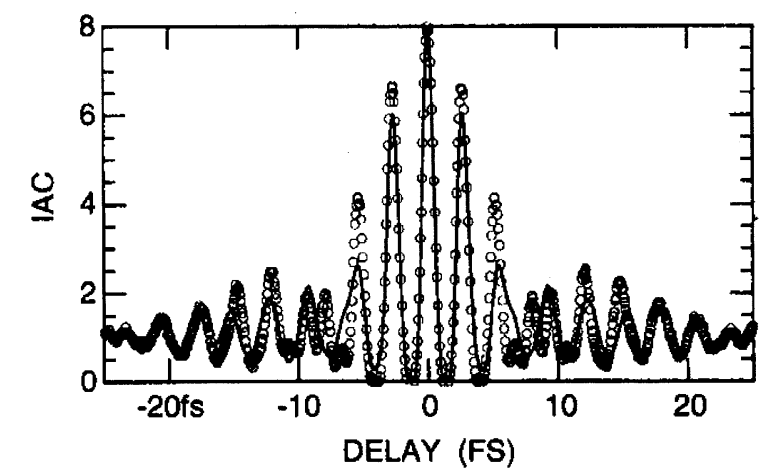

Fig.2 Measured IAC, (dots) and IAC derived from the spectrum assuming zero phase distortions on the spectrum (solid line). (CTuF1, F. X. Kürtner, et al.)

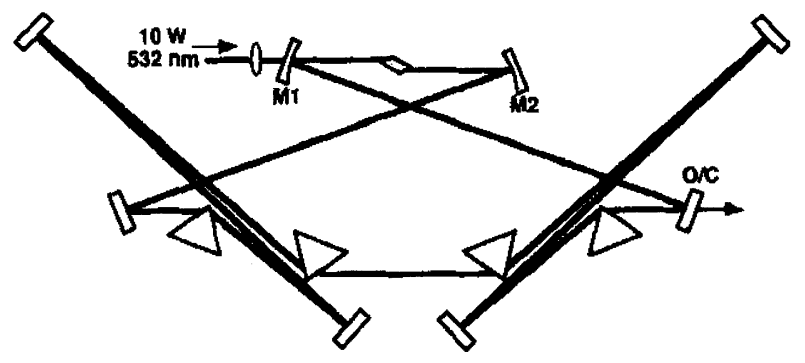

Fig.3 Cavity schematic of self-modelocked Ti:sapphire ring laser. (CTuF2, T. Beddard, et al.)

かる. 平均出力は $1.4 \mathrm{~W}$, 尖頭出力 $1 \mathrm{MW}$, パルスエネルギー $13 \mathrm{~nJ}$ に相当する.このようなリング共振器配置で, 特別仕 様の短いチタンサファイア結晶や薄い反射鏡を用いるこ となしにサブ15fsで高平均出力パルスの発生に成功した.

NTTの鳥塚ら (CTuF3) は, 全固体をモード同期Cr:LiSAF レーザーから,チャープ補償用に13K7プリズム対を用いた 場合に12fs, LaKLプリズム対の場合に10fsというパルスの 発生を行った。

Max Born研究所のPetrovら (CTuF4) は, $\mathrm{MgO}: \mathrm{LiNbO}_{3}$ 結晶

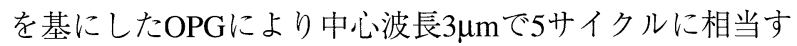
る42fsパルスを発生した。これまでこのスペクトル領域は, $\mathrm{BBO}$ 結晶では発生が困難で, KTP結晶では群速度不整合 (GVM)のため150fs程度のパルス幅しか得られなかったの であるが, GVMの小さい $\mathrm{MgO}: \mathrm{LiNbO}_{3}$ を用いたためこのよ うな短パルス発生が可能になった。

東大の小林ら (CTuF5, 招待講演) は, フェムト秒位相変調 白色光の非同軸パラメトリック増幅にパルスフロント整 合条件を満たすような励起配置をとる装置を開発した。 その概要をFig.4に示す.これにより, 信号光として可視光 領域の550nm-700nmというある程度の広さのスペクトル範 囲で, 波長可変なサブ8fsパルスの発生に成功した。更に, アイドラー光についても, 中心波長 $900 \mathrm{~nm}$ から $1.3 \mu \mathrm{m}$ ま゙の 沂赤外域で波長可変な9fsパルスの発生に成功した。パラ メトリック増幅器の励起には, 再生増幅されたチタンサ ファイアレーザー $(790 \mathrm{~nm}, 1 \mathrm{kHz}$, パルスエネルギー400 $\mu \mathrm{J})$ の第二高調波(パルスエネルギー100 $\mathrm{JJ}$ )を用い,プリズムで 励起パルス面を傾斜させた。増幅されるフェムト秒白色 光は基本波 $(120 \mathrm{fs}, 400 \mu \mathrm{J})$ の極く一部分 $(\sim 1 \mu \mathrm{J})$ を, 厚さ $2 \mathrm{~mm}$ のサファイア板に集光することによって発生させ た。このとき自己収束によって安定な単一フィラメント が形成され, その中でスペクトル再現性の良い自己位相変 調光が発生する。信号光として, Fig.5に示すように,ほぼ フーリエ変換限界であり可視光で最短の $4.7 \mathrm{fs}$ パルスが得ら れた. 非同軸光パラメトリック増幅であるため, 近赤外域 のアイドラー光は必然的に7゚という大きな広がりをもった 角分散を示す。これを補償するため凹面鏡, 円筒面鏡, 回 折格子の組み合わせを用いて, $1 \mathrm{mrad}$ 以下のビームダイ バージェンスにすることができた。またこれを用いてポ リジアセチレンの一重項励起子を励起し, 三重, 二重, 一重 結合の伸縮振動モード間のエネルギーフローを実時間的 に観測した．分子振動モード間のエネルギー移動の様子 を,実時間的に観測したのはこれが初めてである。 


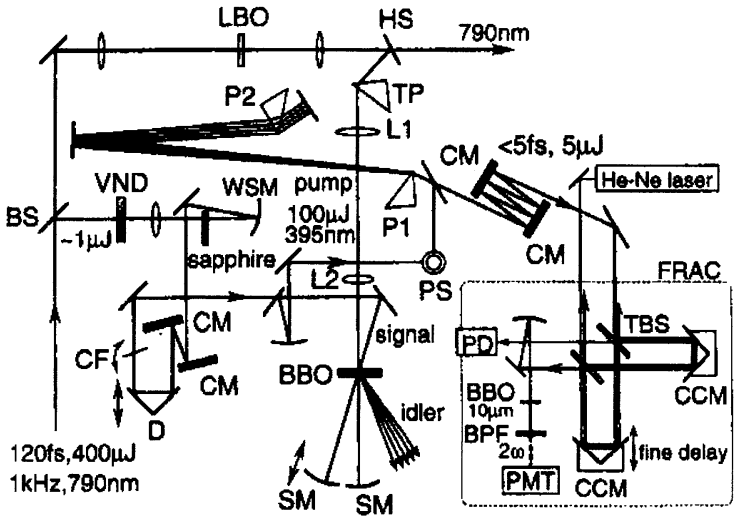

Fig.4 Schematic of the visible sub-5-fs generator. BS, beam sampler, HS, harmonic separator; TP, FS prism for pulse-front tilting; $\mathrm{L}_{1}, \mathrm{~L}_{2}, f=200$ and $f=71-\mathrm{mm}$ lenses; SM's, spherical mirrors ( $r=100 \mathrm{~mm})$; VND, variable neutral-density filter; WSM, spherical mirror $(r=120 \mathrm{~mm})$; CF, cut-off filter; $\mathrm{D}$, optical delay line; PS, periscope; $\mathrm{P}_{1}, \mathrm{P}_{2}, 45^{\circ}$, FS prisms in the minimum deviation; TBS, thin beam splitter; CCM's, corner-cube mirrors; BPF, bandpass filter; PMT, photomultiplier; PD, photodiode. (CTuF5, A. Shirakawa, et al.)
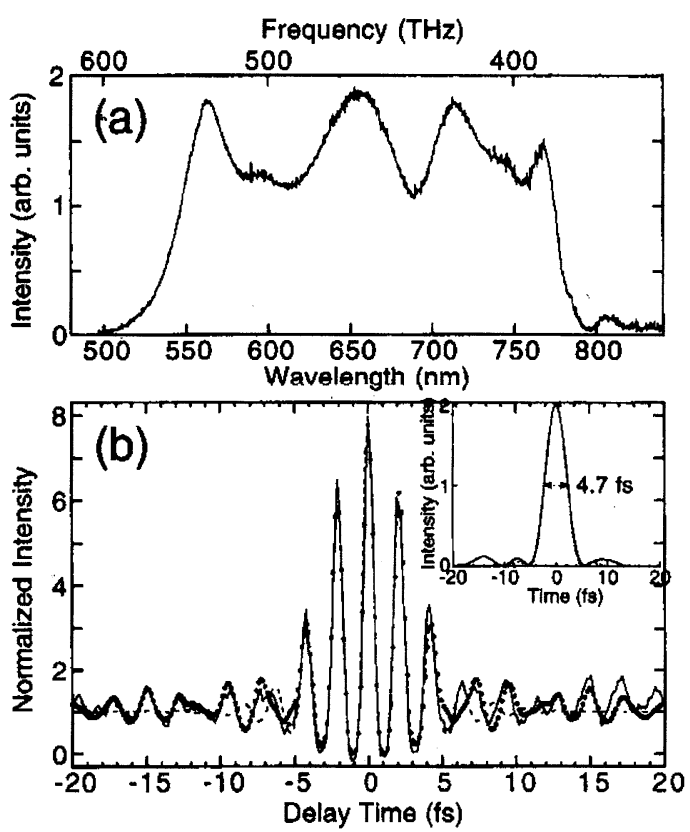

Fig.5 (a) Spectrum of the full-bandwidth signal. (b) FRAC trace of the compressor output. Measured solid curve), FT-fit (full circles) and $\operatorname{sech}^{2}$-fit (dashed curve) traces are shown. In the inset shown are the TL (dashed curve) and estimated (solid curve) intensity profiles. The TL pulse width is $4.4 \mathrm{fs}$, whereas the FT-fit ( $\mathrm{sech}^{2}$-fit) pulse width is $4.7 \mathrm{fs}(3.5 \mathrm{fs})$. (CTuF5, A. Shirakawa, et al.)

短パルスレーザーの超高速光エレクトロニクスへの応 用も盛んである. Allied SignedのNahata (CTuL1) は, 光整流 による電気パルス発生用の高分子薄膜の下の層に形成さ れた共平面ストリップライン型導波路の上下面被ふく層 としてアクリル樹脂を用いた。これにより非線形材料を 含めた全体の誘電率が小さく超高速応答を可能にし,これ までで最短の170fsの電気パルス発生に成功した.

ポストデッドラインペーパーの中でも超高速現象, パル ス発生などの研究発表がかなりの件数あった. Lawrence Berkeley LaboratoryのSchoenleinら (CPD5) はパルス幅30ps のバンチした電子パルスと一緒に $500 \mu \mathrm{J}, 60 \mathrm{fs}, 800 \mathrm{~nm}$ のレー ザーパルスを一緒にウィグラー中を進行させた。フェム ト秒レーザーの強い光電場はウイグラー中で電子を加速 するため,レーザーパルス幅によって決まる短い時間だけ 電子的加速により約 $8 \mathrm{MeV}$ のエネルギー変調を受ける。そ の部分だけ電子ビームに直交する方向へ空間的にシフト させて分離し, その部分からのシンクロトロン放射をパル ス光 $(\mathrm{X}$ 線)として実験に用いる. 残った電子ビームからは ダークソリトン的なシンクロトロン放射が起こり,これが 電子ビームと同期しているので, 電子線と放射光 $(X$ 線 $)$ と を組み合わせたポンプ・プローブ型の実験への応用が考 えられる. 可視域の放射光について, 励起レーザー光との 交差相関をとったところ, 380fsであった。これはウィグ ラーや偏向磁石等の分散効果によるので, それらを改良す ることにより将来100fs以下の放射光パルスの発生も可能 であろうと予測している。東大物性研関川ら (CPD7) は, Xeガスを用いて発生した高次高調波のうち9次よりも高い ものを除いたパルスの多光子イオン化による自己相関波 形を測定することによりパルス幅を計測し, さらに高調波 の負チャープを $1 \mathrm{~mm}$ のLiF板を通過させることにより補償 し, 最短13fsパルスが得られたことを報告した。

QTuJのUltrafast relaxation processesのセッションでは, 主 にバルクあるいは量子井戸構造半導体中の荷電担体, プラ ズモン, 励起子等の超高速なエネルギー緩和や位相緩和に 関する実験が報告された，Karlsruhe大のSteinbachら

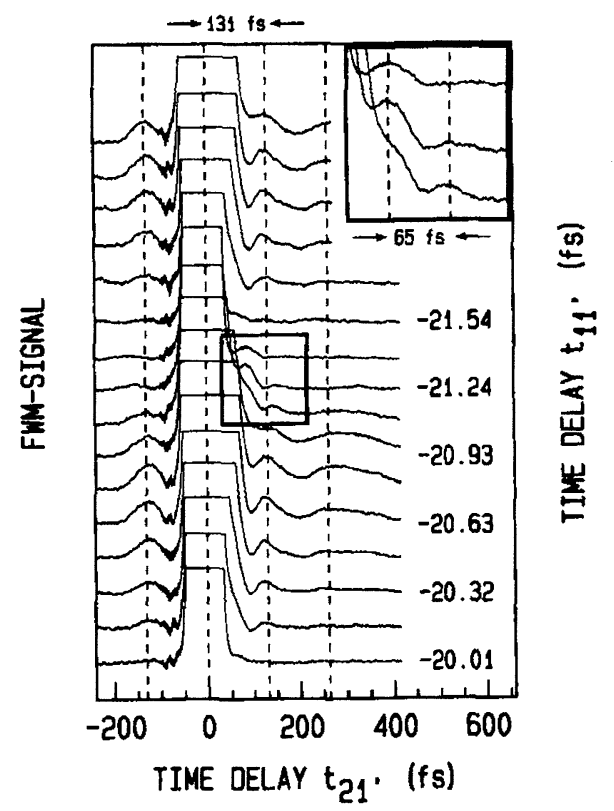

Fig.6 Coherent control FWM-experiment (linear scale) under conditions as (QTuJ1, Fig.1). The time delay of the phaser-locked pulses $t_{11}$, is parameter as indicated. For clarity, the traces are vertically displaced. The prominent 2-phonon oscillation with period $\approx 65 \mathrm{fs}$ $=131 \mathrm{fs} / 2$ is highlighted in the inset. (QTuJ1, Chemla, et al.) 


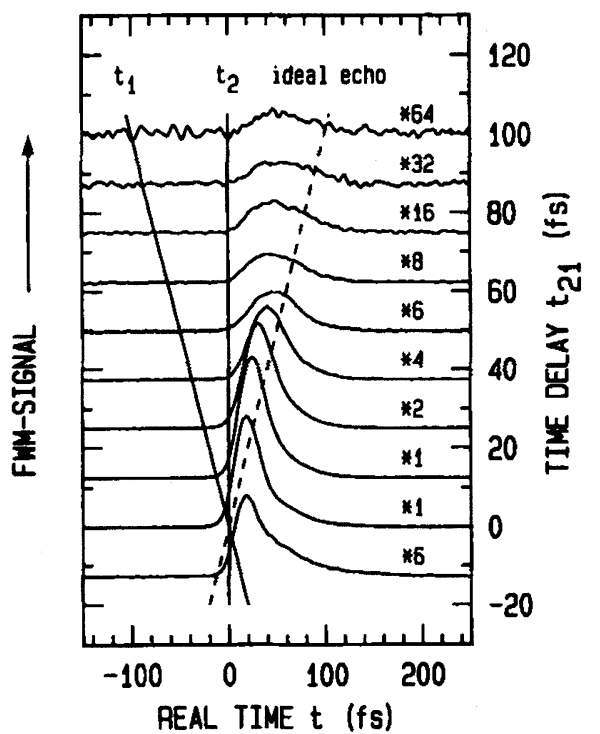

Fig.7 Four-wave mixing signal (linear scale) versus realtime $t$ for selected time delays $t_{21}$ as indicated on the RHS. Also, note the different multiplication factors as indicated. GaAs, $T=399 \mathrm{~K}$, excitation with $\approx 10$ fs optical pulses, $n_{\mathrm{eh}}=2 \times 10^{17} \mathrm{~cm}^{-3}$. The position of the echo for an ideal photon echo is indicated by the dashed line. (QTuJ4, Chemla, et al.)

(QTuJ1) は, 100nm厚のZnSeバルク結晶について13fsパルス を用いた二パルス四光波混合 $(\mathrm{FWM})$ の実験を行った。そ のFWM信号の中に $n=1$ フォノン以外に $n=2$ フォノンによ る信号も見出した．位相をロックした二パルスをFWMの 第二パルスの代わりに入射し，その位相を変えることによ り, $n=1$ フォノンの信号を抑制し, $n=2$ フォノン信号を強 めたり逆にしたりするコヒーレント制御の実験を行った (Fig.6). Karlsruhe大のHugelら (QTuJ4)は, 10fsパルスを用 いて至温300KでGaAsの位相緩和でエコー信号が指数関数 的に減衰することを示した，第一, 第二パルス間隔を $t_{21}=$ $t_{2}-t_{1}$ とした場合, 時間分解信号は, $t_{21}<0$ の場合に片側指 数関数の形から, $0<t_{21}<50 \mathrm{fs}$ では通常のフォトンエコー と同じような $t=t_{21}$ に極大をもつ信号が現れる (Fig.7,8). 更に, $t_{21}>50 \mathrm{fs}$ では波形は対称に近くなり, 理想的なエコー の場合より, 遅延が短くなり, 信号パルス幅は広がる。こ の結果は, 伝導帯の高いエネルギーの電子はより速い位相 緩和を示すことで説明され, $15 \mathrm{fs}$ の時間積分エコー信号減 衰時間は, 平均的な值にすぎない. $t_{21}=0$ 近辺で現れる約 $50 \mathrm{fs}$ の周期的信号は, 非マルコフ的電子一電子散乱に依る という以前同じグループの実験から出された結論と整合 している.

他にも多数興味深い研究発表がなされたが紙数の都合 で割愛させていただく。

(小林 孝嘉)

\section{3. 高出力超短パルスレーザー}

ここ数年, レーザー技術に関しては, 高出力超短パルス チタンサファイアレーザーのピーク強度の記録更新が話 題の一つであったが, 最近一服の感がある. 今年は, 背景 光の強度比やアダプティブオプティックスを用いた波面
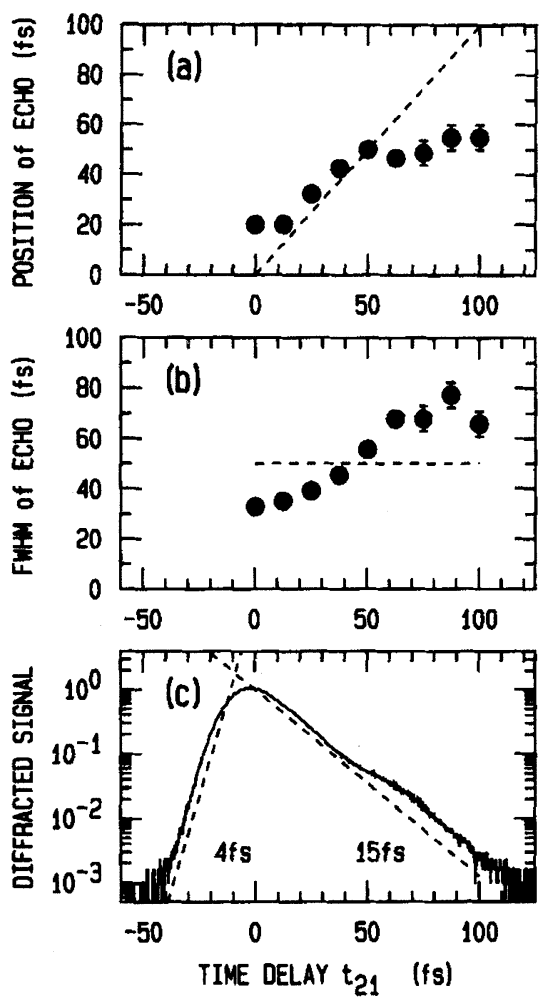

Fig. 8 The position (a) and the width (b) (full width at half maximum FWHM) in realtime of the FWM-signal versus time delay $t_{21}$ as extracted form the data shown in (QTuJ4, Fig.1). The dashed lines show the behavior of and ideal echo. The time-integrated FWMsignal is shown for reference (c). (QTuJ4, Chemla, et al.)

制御など,パルスの“クリーン度”を向上し実際の集光強度 を上げる方向に関心が向かっていた。

まず, CTuD1でミシガン大学のWangらが40TW, $10 \mathrm{~Hz}$ フェムト秒チタンサファイアレーザーの開発の報告を 行った. レーザー物理, 技術の観点からは新しいことはな かったが, FROGによる位相測定, 集光径, 背景光との強度 比の性能評価を行っていた. CTuD2では, UCサンディエゴ 校のグループが60TWチタンサファイアレーザーの開発と その性能評価の報告を行った。ヘリウムガスのイオン化 で強度の校正を行い(Fig.9), 最終的な集光エネルギーは5 $\times 10^{19} \mathrm{~W} / \mathrm{cm}^{2}$ と見積もっていた. その光をアルゴンガスへ 集光し16価のイオンまで観測した. CTuD3は招待講演で, $1.1 \mathrm{TW}$, 繰り返し $1 \mathrm{kHz}$ チタンサファイアレーザーの開発が フランスのグループから報告された. 5台ものNd:YLFレー ザーを用い, 再生増幅, 3段のマルチパスによる増幅を行っ ている(Fig.10). stretcherでの波面のゆがみがパルス圧縮 後のパルスの裾になるとし, $\lambda / 40$ と/100の鏡を使って stretcherを構成した。 また, 再生増幅器中でのスペクトルの 狭帯域化を防ぐため, 複屈折フィルターを用いてスペクト ルコントロールを行っている. マルチパス増幅は熱レン ズ効果を考慮して設計を行った。 増幅中に得る分散が非 常に多いため, 最終的なパルス圧縮はstretcherと異なる刻み の回折格子 (stretcherでは $1200 \ell / \mathrm{mm}$, compressorでは 1500 $\ell / \mathrm{mm})$ を用いて行った. 最終的には18.5fsのパルス幅を得 

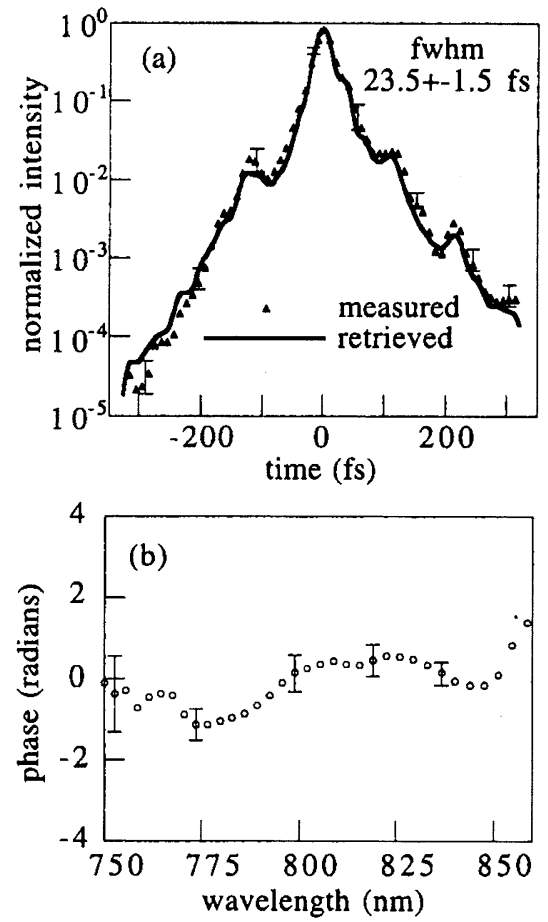

Fig.9 Mean and standard deviation of the experimental and retrieved PGFROG time marginal (a). Mean and standard deviation of the retrieved spectral phase (b). (CTuD2, B. C. Walker, et al.)

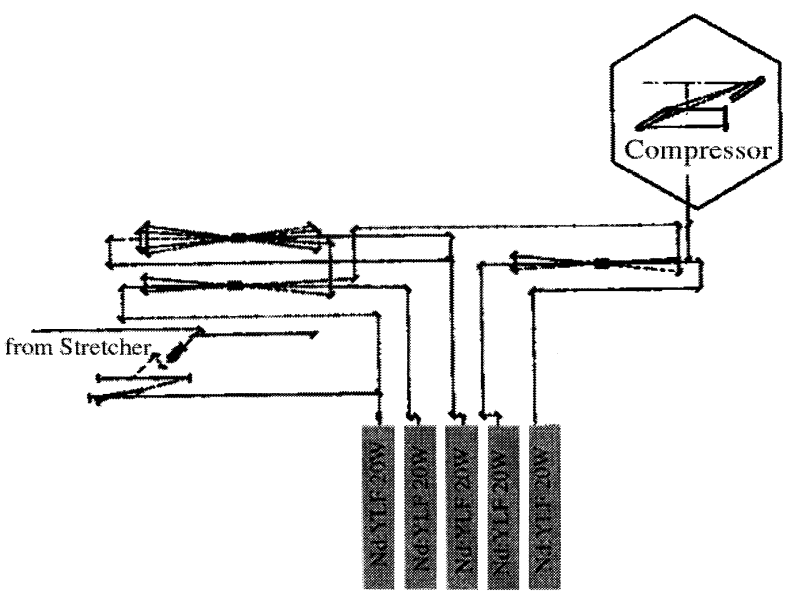

Fig.10 Amplifier experimental setup. (CTuD3, V. Bagnoud, et al.)

た Fig.11). パルスの背景光との強度比は $10^{-4}$ と報告して いた。これに関連して, CWF16で同じグループが複屈折 フィルターを使った再生増幅器の報告をしていた。複屈 折フィルターをスペクトルコントロールに使う問題点と して, 裏面反射により主パルスの裾に子パルスができるこ とをあげていた，その強度比は10-2であった，CTuD4では， ミシガン大学のMourou教授のグループから, deformable mirrorを用いた波面整形の報告があった。パルス増幅中， 光学素子の不完全性, 熱, Kerr効果などによりパルスの波面 が乱れ集光径が大きくなってしまうが, deformable mirrorに より補償することができる。講演では, チタンサファイア， Nd:glassのハイブリッドレーザーの基本波, 第二高調波がほ ぼ回折限界まで絞れることを示した(Fig.12)，第二高調波

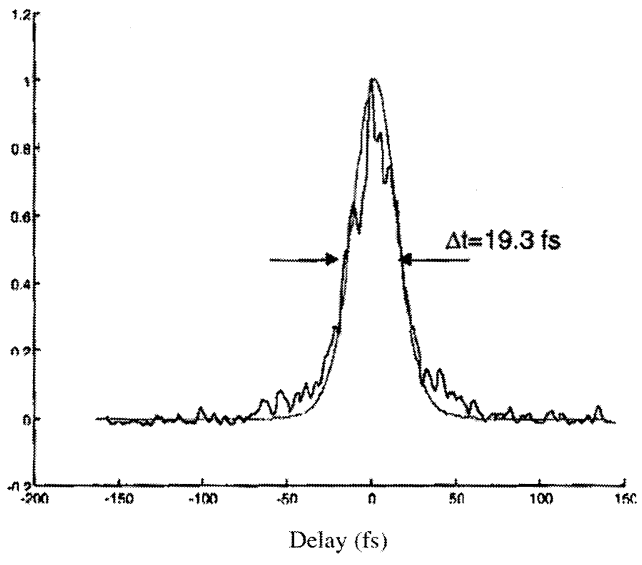

Fig.11 Autocorrelation function of the amplified pulses. The deconvolution gives a $19.3 \pm 2$ fs duration. (CTuD3, V. Bagnoud, et al.)

を発生させることは,パルスの裾を落とす効果もあり実効 的な集光強度を上げる. CTuD5でも, deformable mirrorを用 いたTWレーザーの波面整形の報告がフランスのLULIのグ ループからあった。CTuD6ではCTuD4に関連し, KDP結晶 を2枚用いて群速度遅延を補償して $60 \%$ の高効率で第二高 調波を発生させ (Fig13), deformable mirrorを使って2 $10^{19} \mathrm{~W} / \mathrm{cm}^{2}$ に集光した結果が報告された。CTuD7では, TW 炭酸ガスレーザーを用いて電子加速を行おうとする試み が報告された. ponderomotiveエネルギーは波長の2乗に比 例するので, 長波長のレーザーを用いるのが得策というこ とであった。

応用では, 近年, 可視以上の長波長の超短パルスレーザー を,様々な方法でX線領域へ変換する研究が盛んに行われて いる．その観点から, JTuD1でのミシガン大学のUmstadter

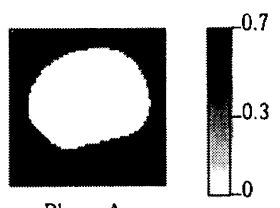

Phase B

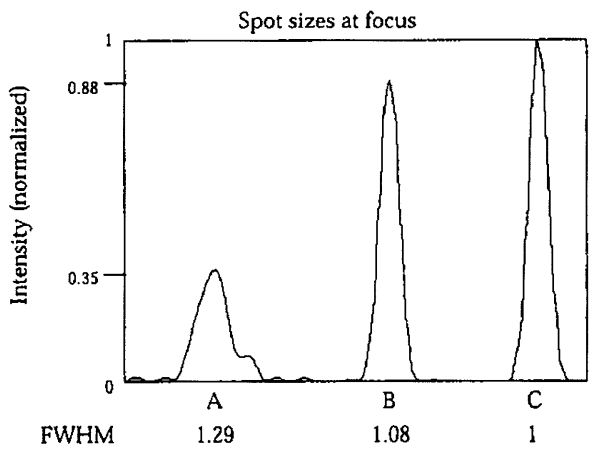

Fig.12 Experimental phase of the laser: Distorted (A), 0.7 $\lambda$ peak-to-valley and corrected (B), 0.3 peak-to peak. Below is represented a lineout of the calculated focal spot knowing the phase and the intensity of the beam: A, distorted beam, B corrected beam, $\mathrm{C}$ flat phase (diffraction limited). (CTuD4, J. Queneuille, et al.) 


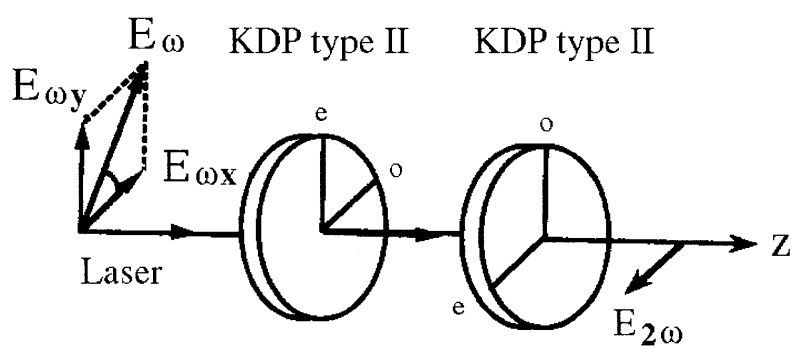

Fig.13 Schematic of SHG in KDP type II crystal with predelay. (CTuD6, A. Maksimchuk, et al.)

の相対論領域での電子と光の相互作用の報告やCPD5の ローレンスバークレー研究所のSchoenleinのフェムト秒シ ンクロトロン光源を開発したとの報告が興味深かった。 後者のフェムト秒シンクロトロン放射光の発生機構は次 の通りである．シンクロトロンの電子バンチとフェムト 秒レーザーの相互作用によりパルス幅と同程度の時間広 がりを持つ電子バンチを取り出す．放射光の時間幅は電 子バンチの時間的広がりで決まるので, 切り出された電子 バンチからの放射光はフェムト秒の時間幅を持つ (Fig.14). シンクロトロン放射光であるため, 硬X線から赤 外領域までのスペクトルをもっており, 波長可変である点
が非常に特徵的である. 報告では, 可視域の光をチタンサ ファイアレーザーとの交差相関法で測定した例を示し た.もともと $17 \mathrm{ps}$ 程度であったシンクロトロン放射光から 60fsのチタンサファイアレーザーで切り出された光のパル ス幅は, 161fsであった。 パルス幅は, シンクロトロン軌道 内での分散によって広がっている。もとの電子バンチの うち, 切り出された部分は電子の数が減り凹むはずであ る。実際に測定すると $112 \mathrm{fs}$ のんだ放射光が発生してお り, 凹んだ部分をdark pulseと呼んでいた(Fig.15)。この様 に高出力超短パルスレーザー開発の進展に伴い高出力超 短パルスレーザーの応用も多岐にわたるようになった。 高出力超短パルスレーザー技術, 高強度電場下での物理の 更なる進歩のみならず, 今後は, 高出力超短パルスレーザー を励起光源とした短波長光源の実用化による高出力超短 パルスレーザーの多くの研究者への普及を期待したい.

(関川 太郎)

\section{4. 短波長コヒーレント光源}

本章では,はじめに高次高調波の発生とパルス圧縮につ いての報告, 次に軌道放射光のフェムト秒パルス化につい ての報告, 最後に軟X線レーザーについての報告をする.

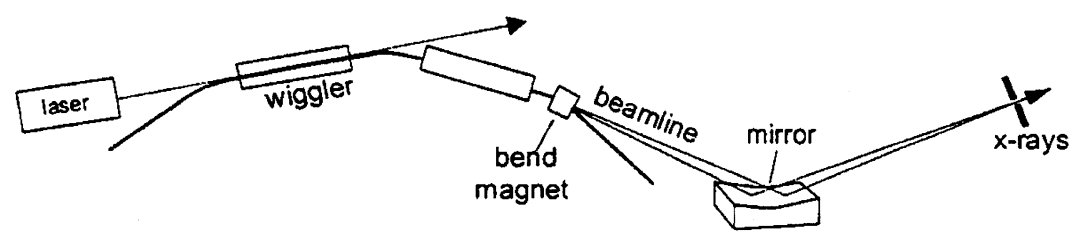

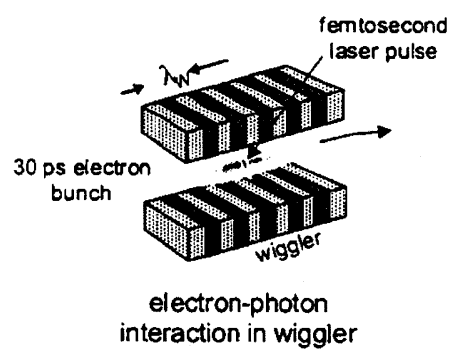

(a)

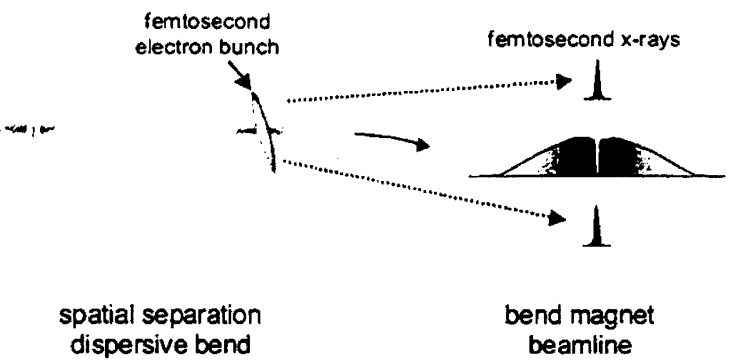

(b)

(c)

Fig.14 Schematic illustration of the technique for generating femtosecond synchrotron pulses. (a) laser/electron beam interaction in resonantly-tuned wiggler, (b) separation of accelerated femtosecond electron slice in a dispersive (bend) section, and (c) generation of femtosecond x-rays at a band-magnet beamline. (CPD5, R. W. Schoenlein, et al.)

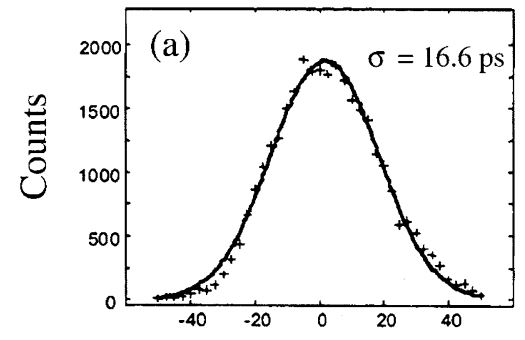

Delay (fs)

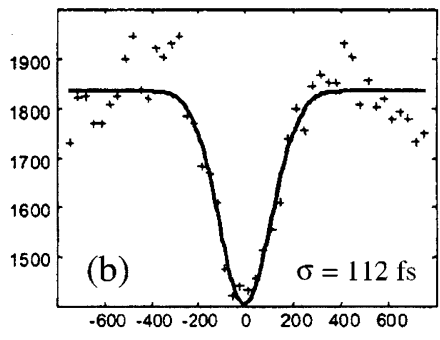

Delay (fs)

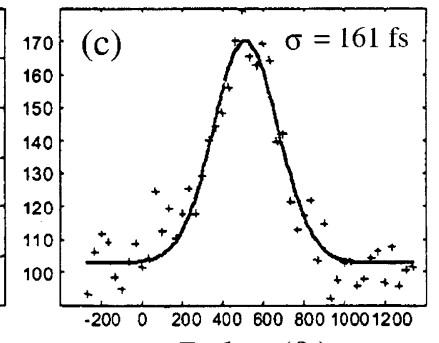

Delay (fs)

Fig.15 Cross correlation of visible synchrotron pulse with femtosecond laser pulse (and schematic illustration of the corresponding region of the electron bunch): (a) overall synchrotron pulse, (b) femtosecond dark pulse from on-axis radiation, and (c) femtosecond pulse from off-axis radiation. (CPD5, R. W. Schoenlein, et al.) 
高次高調波とは高次の非線形光学現象により発生する ものである. 直線偏光のレーザーパルスを $10^{14} \mathrm{~W} / \mathrm{cm}^{2}$ 以上 の強度で原子ガスに照射すると著しい非線形効果により 数十次, 数百次の高調波が発生する。97年には高次高調波 の最短波長が水の空域に達した。残るテーマは発生効率 の増大とアト秒パルス発生の2つである.

玉木ら (JWA2) は, レーザーガイディングを利用した高 調波の発生効率増大についての招待講演を行った。近赤 外レーザーパルスと高次高調波との位相整合により,レー ザーガイディングによる相互作用長の増大を実現し, 高調 波の発生効率が二桁以上に増大したことを示した。これ は巨視的位相整合と微視的位相整合の組み合わせにより 常に高次側の高調波のみが増幅されることによると考察 した. Fig.16が観測された軟X線スペクトルであり，媒質や ガイディング法によらず常に高次側のみが位相整合が満 たされて高調波の発生効率が増大していることを確認し ている，ガイディング法としては中空ファイバを用いた 方法と自己導波現象を利用した方法を用いた。CUOS (Center for Ultrafast Optical Science)のDurfeeら (JWA1) も 中空ファイバを用いて4種類のガスにおいて常に高次側の 高調波だけが増加すると報告し，昨年の報告での常に27次 だけ増加するという結果から訂正していた。これらの報 告により,高調波の問題点であった変換効率という点が改 善され,この方法論がさらなる変換効率の増大を導くと考 えられている。

高次高調波の目を見張るべき特徵はその時間分解能で

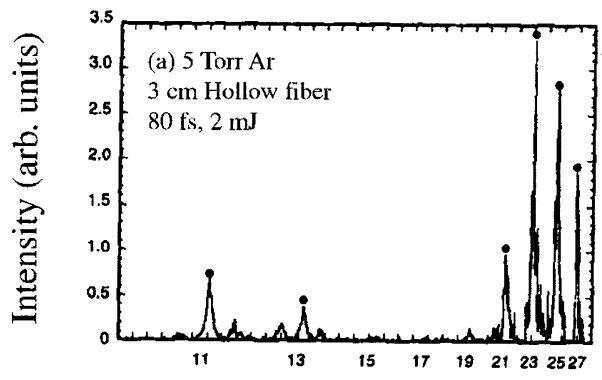

Harmonic order

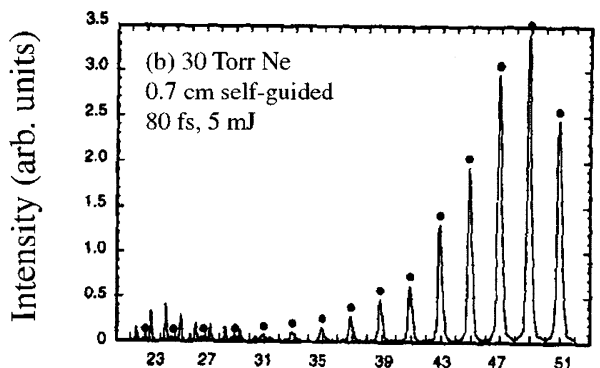

Harmonic order

Fig.16 Observed high-harmonic spectra. (a) was obtained with uncalibrated spectrograph when $2 \mathrm{~mJ}, 80 \mathrm{fs}$ Ti:sapphire laser pulses propagated in a 3-cm Arfilled hollow fiber. (b) was obtained when $5 \mathrm{~mJ}$, $80 \mathrm{fs}$ laser pulses in 30-Torr neon gas. Line emission appeared on both sides of lower order harmonics are the second-order diffraction of higher order harmonics. Dots emphasize harmonic intensities of first-order diffraction. (JWA3, Y. Tamaki, et al.)
ある。高調波のパルス幅や時間位相を測定することによ り, 高次高調波の発生メカニズムはもちろんのこと, 非常 に魅力的な「軟X線アト秒パルス発生」への指針が得られ る.

物性研の関川ら (CPD7) はポストデッドラインペーパー で高調波の時間位相の測定法を開発し，また応用としてパ ルス圧縮のデモンストレーションを行った。Fig.17に示す 実験装置でヘリウム原子の4光子イオン化を利用して5次 高調波の自己相関波形を測定し, 高調波に分散を与えたと きのパルス幅変化を観測した。高調波の負分散が励起 レーザー強度の変化によって与えられている様子がFig.18 に明解に示されている。この実験結果からTi:sapphireレー ザーシステムのcompressorのグレーティング間隔の最適位 置からの変化量が士 $400 \mu \mathrm{m}$ の近傍でレーザー強度がちょう どLiFによる正分散を打ち消す負分散を持つことが分か る。これに対して最適位置ではレーザー強度が強すぎる ために負分散が大きすぎてパルス幅が広がってしまう。

また挿入するLiF板の厚さとパルス幅の関係からチャープ 量を導き出した。この2つの独立した方法によってどちら の方法でもレーザー強度が与える負分散量が ponderomotive

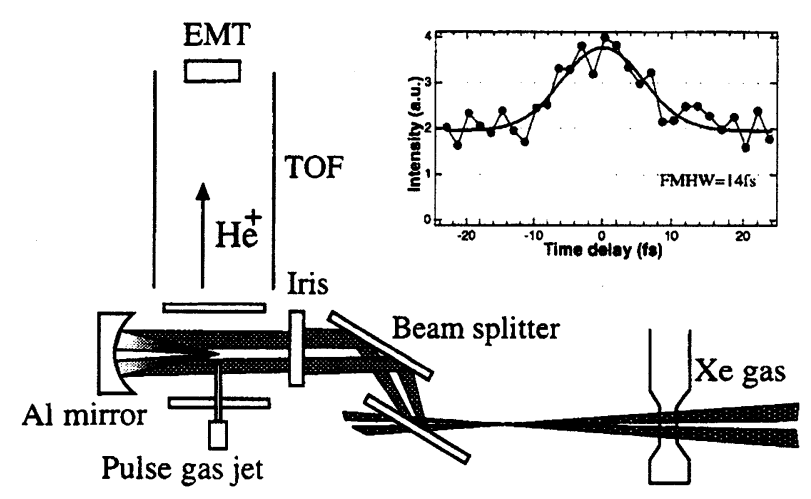

Fig.17 Experimental setup for the forth-order autocorrelation measurement. The inset shows the autocorrelation function, of which FMHW is $14 \mathrm{fs}$ corresponding to the pulse width of $13 \mathrm{fs}$. (CPD7, T. Sekikawa, et al.)

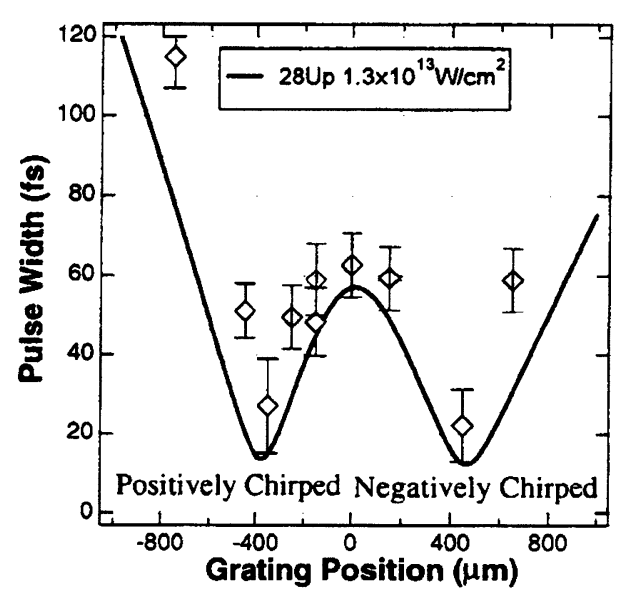

Fig.18 Pulse width of the 5th harmonic as a function of the laser chirp after passing through a LiF plate of thickness $1 \mathrm{~mm}$. The atomic dipole phase is proportional to 28Up. (CPD7, T. Sekikawa, et al.) 
energyの25倍という同じ結果を得た. これらの結果から最 適な実験条件を導き, $115 \mathrm{fs}$ 励起で13fsの高調波出力を得 た。より高いイオン状態を利用することにより原理的に はさらに高い次数の自己相関波形を得ることも期待でき

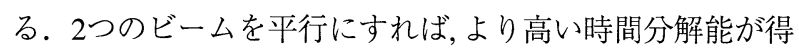
られ平行状態が達成されれば原理的にはフェムト秒以下 のパルス測定も可能である。

もう一つのアト秒発生に関する発表は, Univ. of Michigan のDurfeeら (QPD3)のポストデッドラインペーパーであ る. 基本波と第2高調波を中空ファイバへ入射し,アルゴン ガス密度を増加していくと高調波の放射が消えるという 予稿での結果はさておき,アルゴンで31次からカットオフ 次数の39次まで非常にスムースなスペクトル発生を観測 したという話があった。このようなカットオフ近傍での 特殊なスペクトル構造は, 31次から39次までの高調波の発 生において発生源である電子の軌道が単一であることに 起因する. 微視的な電子軌道が同じであることから, 巨視 的な伝搬によってスペクトル構造が乱されない.このス ペクトル領域では高次の分散が小さく非常に圧縮しやす い. 前述する高調波の圧縮との組み合わせでアト秒軟X線 パルス発生に大きく前進しつつある.

高次高調波以外の超短パルスのX線発生源としては, 電 子ビームとフェムト秒レーザーとの相互作用を利用した ものがある. Lawrence Berkeley National Laboratoryの Shoenleinら (CPD5) はAdvanced Light Sourceからのパルス幅

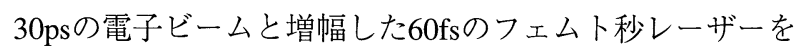
同軸上で重ね, 電子ビームの一部を光励起した. Fig.14が 実験の概念図であり, Fig.15が得られた結果である．Fig.15 (a)が30ps電子ビームから放射された光のパルス波形であ り,この中心部分がフェムト秒レーザーとの相互作用に よって切り取られている. Fig.15 (b)がその暗パルスを示 したものであり, Fig.15 (c)が励起された電子ビームのみか ら放射された光のパルス波形である. 軌道放射光はどの スペクトルでも同じ時間波形で発生するのでこの結果は 直ちにフェムト秒X線パルスの発生の実現と換言できる.

Colorado State UniversityのRoccaら (JWC6, JWC7) は小型 で高平均出力かつ高コヒーレンスなキャピラリー放電型 軟X線レーザーについて発表した. 波長 $46.9 \mathrm{~nm}, \Delta \lambda / \lambda=$ $10^{-4}$ のスペクトル幅, $7 \mathrm{~Hz}$ の繰り返し動作で平均出力 $1 \mathrm{~mW}$ 上, ピーク出力 $100 \mathrm{~kW}$ 以, 連続運転可能時間 30 分, レー。 ザーサイズ $1 \mathrm{~m} \times 0.4 \mathrm{~m}$ とい素晴らしい装置である。この 波長での輝度を軌道放射光と比べると $10^{5}$ 以上であり,この レーザーはすでに産業利用に近いレベルに達している。 是非予稿集と合わせてOpt. Lett. 22 (1997) 796をご覧頂き たい.

最後に, これらの研究分野でキーとなる技術は高出力の フェムト秒レーザーである，成熟しつつあるフェムト秒 レーザーの次のステップは先端的にはスペクトル整形と スペクトル位相制御そして波面制御の組み合わせによる ピーク強度の増加であろう。また電源まで含めたシステ ムの小型化が応用上課題になってくるだろう. 特に, フェ ムト秒レーザーの心臓である発振器の小型化・安定化に 加えて高繰り返し化・高パルスエネルギー化が強く望ま
れる。

(玉木裕介)

\section{5. 半導体レーザー}

半導体レーザー関連としてはCLEOにおいて12のセッ ションがあった。その中でも最も多かったセッションが 面発光レーザー関連の3セッション, ついで, 可視光レー ザー, 通信用レーザーの2セッションと続く.やはり米国で の面発光レーザーの人気は高く, 日本国内との大きな温度 差を感じた. 光データコムの需要に伴って当分この人気 は維持しそうである。

面発光レーザーのセッションにおいては, $1.55 \mu \mathrm{m}$ 帯面発 光レーザーに進展が見られた。これまでこの波長帯の面 発光レーザーは, GaAs系の面発光レーザーにくらべ電気, 光学特性のよい反射鏡がないということが問題であっ た.フランスOpto+のStarckらはFig.19のようにInP上に非 常に格子の異なる GaAs/AlAs反射鏡を製作することを可能 とし室温連続動作で $1 \mathrm{~mW}$ 以の出力を出す事に成功した (CThO1).また, カリフォルニア大学のAlmuneauらはInP 上に格子整合可能な $\mathrm{AlGaAsSb} / \mathrm{AlAsSb}$ 反射鏡を使い面発光 レーザーを製作し室温パルス動作ながら $7 \mathrm{~mW}$ 近くの光出 力を実現している(Fig.20). 現在のところデバイスの抵抗 が高いようであるが, これは, 成長上のミスで, すぐ解決で きるとのことである(CPD16).このいずれのデバイスも電 流注入にトンネル接合を用いていることがポイントで,こ れにより反射鏡の電気特性の悪さを解決している。一方 で面発光レーザーの出力光制御にも関心が寄せられ，(311） 基板を利用した偏波制御面発光レーザー(CThU5)をはじ め,様々な偏波制御法についての報告が行われた。新しい ものとしては京大のImadaらにより2次元フォトニック結 晶を導入した面発光レーザーの報告も行われた (CThO2).また, 隣り合った素子をカップリングさせ素子

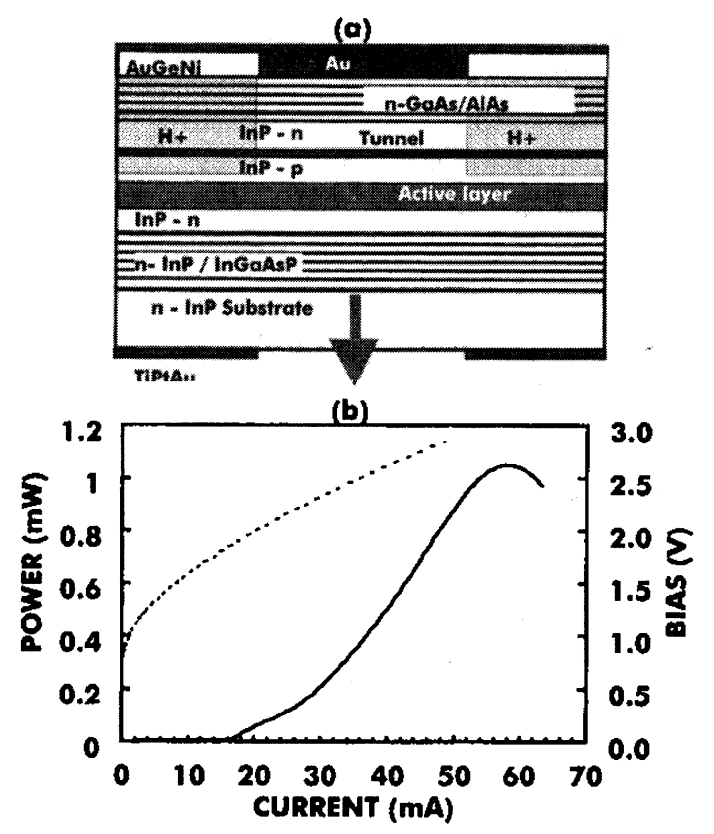

Fig.19 Structure and light-current-voltage characteristics of the planar proton implanted metamorphic tunnel junction VCSEL. (CThO1, C. Starck et al.) 


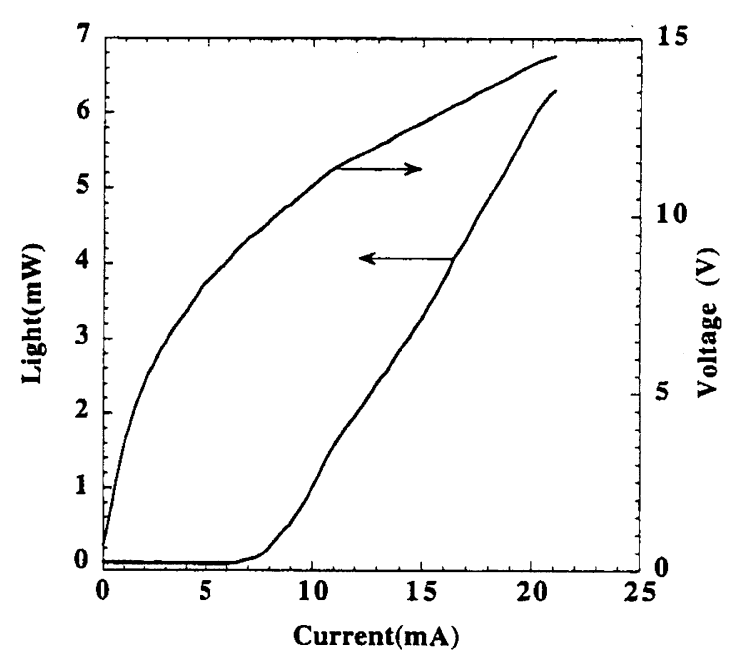

Fig.20 Light power and applied voltage as a function of the injected current at room temperature. (CPD16, G. Almuneau et al.)

間での出力光の位相をそろえるといった試みも報告され た(CPD25).

GaN系青色レーザーでは, あまり目だった進渉は報告さ れなかった。ひとまず主な研究機関はcw発振を達成し,そ の先で停滞しているという感じであろうか? その中でも HVPE選択成長で垂直ファセットをもつ六角柱を製作し， 光ポンプでの共振 (周回モード, 縦方向ともに)の報告 (CTuI6)や, 活性層のバリア層の組成を非対称にすること によりピエゾ効果による発光効率低下を抑えるという方 法の提案 $(\mathrm{CTuU} 2)$ などが行われた。また, 日本では既に応 用物理学会や電子情報通信学会等で発表が行われている が東大の荒川教授のグループによるInGaN光励起面発光 レーザー(CPD15) (Fig.21), InGaN-量子ドットレーザーが それぞれCLEO, QELSで報告が行われた。

通信用レーザーでは, DBRレーザーに関する報告が多 かった。 また, 近年めざましい進歩を遂げている量子ドッ

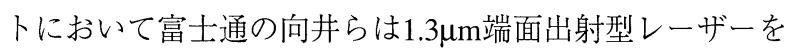
報告した。その光出力特性をFig.22に示す。低成長レート， InにaAsによるInAsドットのカバーにより高密度ふつ比較 的大きな量子ドットを実現し, 波長 $1.3 \mu \mathrm{m}$ での発振へとつ ながったようである。しきい值は $25^{\circ} \mathrm{Cにおいて} 8 \mathrm{~mA}$ と比 較的低い(CPD18). 今後の展開が楽しみである.

中赤外波長のレーザーにおいては, Sb系のType II量子井 戸レーザーに関し多くの発表が行われた。この系では Type IIであることによる発光効率の悪さと電流注入, 室温 による発振が困難という問題を抱えているが, 着実にそれ は解決しつつある印象を受けた。波長域3～6 $\mu \mathrm{m}$ での $200 \mathrm{~K}$ 以上における光ポンプcw動作 $(\mathrm{CThE} 3)$ や, 電流注入型デバ イスでの高出力動作 $(\mathrm{CThE5})$ などが報告された. 一方, カ スケードレーザーではFig.23のように活性層としてバリア 層を薄くし隣の井戸とカップリングさせたバンドを形成 し, 発光させるといった超格子カスケードレーザーの報告 がLucentのベル研究所やノースウェスタン大学などからあ り発光波長 $17 \mu \mathrm{m}$ での発振 $(\mathrm{JMA} 4)$ や, 発振波長 $7.3 \mu \mathrm{m}$ で

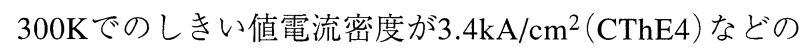
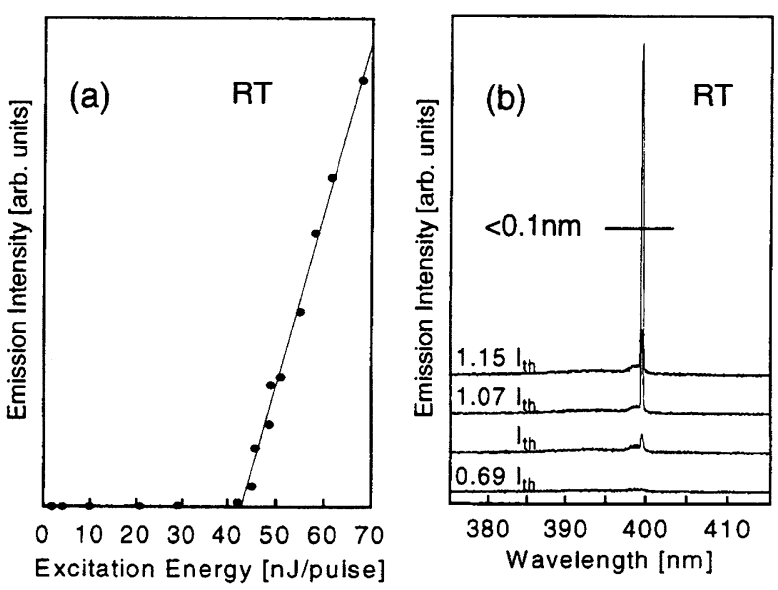

Fig.21 Emission from the single VCSEL was measured at room temperature. (a) Emission intensities accumulated for 180 pulses are plotted as a function of excitation energy per one pulse. (b) Emission spectra from the VCSEL at various excitaion powers are shown. The spectral linewidth drastically changed from $0.9 \mathrm{~nm}$ below threshold to less than $0.1 \mathrm{~nm}$ (resolution limit) above threshold. (CPD15, T. Someya et al.)

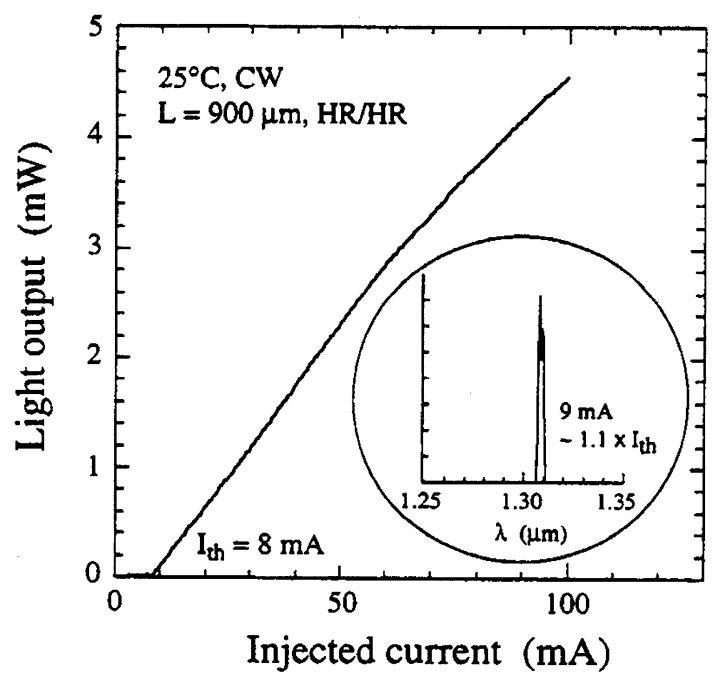

Fig.22 CW light output versus injected current characteristics. Threshold current $\left(I_{\text {th }}\right)$ was $8 \mathrm{~mA}$. Lasing spectra at $9 \mathrm{~mA}\left(\sim 1.1 \times I_{\text {th }}\right)$ is shown as an inset, indicating the lasing wavelength of $1.31 \mu \mathrm{m}$. (CPD18, K. Mukai, et al.)

データを示していた。

高出力レーザーでは, 様々な波長での高出力化について 報告された．しかもほとんどのデバイスで電気变換効率 が50\%程度まで達しており, 高効率動作を実現している。

全体の印象としては, 特に目立ったものはないが, それ ぞれが着実に進歩しつつあるという感じである。ただ,気 になるのは日本の研究機関の元気のなさであり, 経済状況 もあるとは思うが, 活躍を期待したいものである.

(西山 伸彦) 


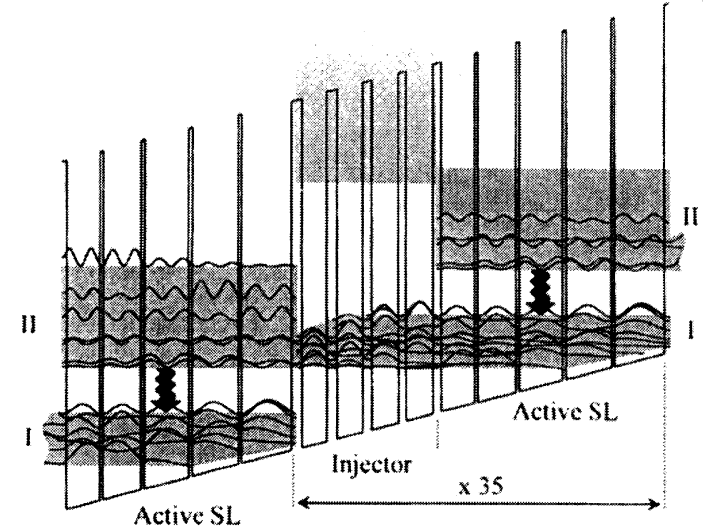

Fig.23 Conduction band profile of two chirped SL active regions with the connecting injector under an applied electric field of $2.05 \times 10^{4} \mathrm{~V} / \mathrm{cm}$. The moduli squared of the wavefunctions and the two minibands into which the states are grouped are also shown. The lifetimes are determined by optical phonon emission and for the lowest state of miniband II we compute at cryogenic temperature $\tau_{\mathrm{II}}=0.5 \mathrm{ps}$, while for the uppermost state of miniband I we obtain $\tau_{\mathrm{I}}<0.3 \mathrm{ps}$, with a relaxation time between them of $\tau_{\mathrm{II}, \mathrm{I}}=3.6 \mathrm{ps}$. (JMA4, A. Tredicucci, et al.)

\section{6. 波長変換素子}

非線形光学結㫛を利用した波長変換については,いくつ かのセッションに分かれて報告があった。この分野の傾 向として, 紫外光発生に優れた $\mathrm{CsLiB}_{6} \mathrm{O}_{10}(\mathrm{CLBO}), \beta$ $\mathrm{BaB}_{2} \mathrm{O}_{4}(\mathrm{BBO})$, 可視から近紫外域の変換に適した $\mathrm{LiB}_{3} \mathrm{O}_{5}$ (LBO) などは, 既に基本的な変換特性が調べられているの で, 実際にそれらを組み込んだシステムの報告が多く, 赤 外光領域では疑似位相整合型のperiodically poled $\mathrm{LiNbO}_{3}$ (PPLN) やperiodically poled $\mathrm{KTiOPO}_{4}(\mathrm{PPKTP})$ などを用いた OPOについての発表が多かった。ここでは「Diode-Pumped Neodymium Lasers」, 「Frequency Conversion I $\sim$ III $\rfloor$, 「Ultraviolet Generation」, 「Nonlinear Optical Crystals」等のセッ ションから,材料を中心に興味を引いたものを紹介する。

オーストラリアのMacquarie大学からは, $\mathrm{LiIO}_{3}$ 結晶の誘 導ラマン散乱とLBOの第2高調波発生を利用した全固体黄 色レーザー光源の報告があった(CMA3)．LD励起Nd:YAG レーザーの共振器内部に $2 つ$ 結晶を挿入して, $0.96 \mathrm{~W}$ $(7 \mathrm{kHz})$ の高出力を得ている. $\mathrm{LiIO}_{3}$ から発生する1次ストー クス光の波長は $1160 \mathrm{~nm}$ で, LBOは温度調節によってその第 2高調波を非臨界位相整合条件で発生させることができ る.

ドイツのMax-Born-Instituteから $\mathrm{KB}_{5} \mathrm{O}_{8} \cdot 4 \mathrm{H}_{2} \mathrm{O}(\mathrm{KB} 5)$ 結晶 を用いた真空紫外光 (波長：166nm)の発生が報告された (Fig.24)。100fsのTi:sapphireレーザー $(600 \mu \mathrm{J}, 1 \mathrm{kHz})$ を基本 光源として, 赤外光の $\mathrm{OPG}(1.15-1.6 \mu \mathrm{m})$ と第4高調波 $(189-$ $210 \mathrm{~nm})$ の発生を行っている。これらをKB5 $(5 \times 5 \times 0.5 \mathrm{~mm}$, $y$ 軸)に入射させ, 和周波発生によって166-172nmの真空紫 外光を得ている。この時のパルス幅は200-220fsである. $\mathrm{KB} 5$ は実効非線形光学定数が $0.04 \mathrm{pm} / \mathrm{V}$ と小さいものの, 大

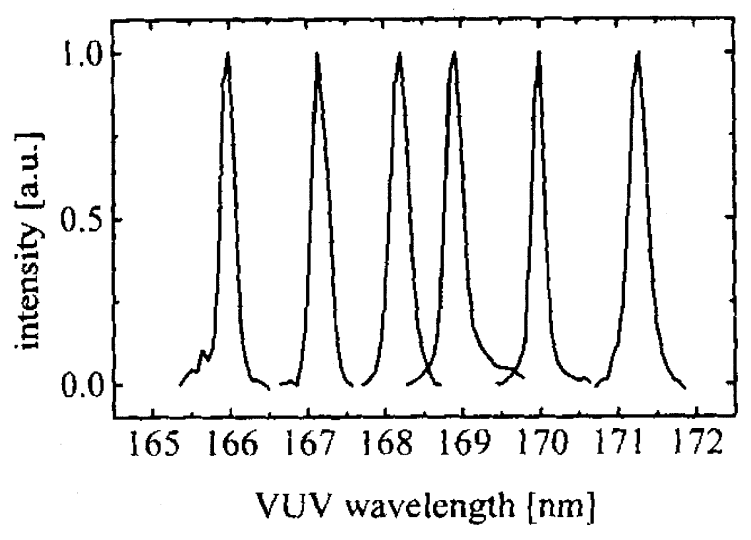

Fig.24 Normalized VUV spectra demonstrating the achieved SFG tuning range. Both the $\mathrm{FH}$ and the signal wavelengths were varied here to satisfy the condition for noncritical phase-matching along the $y$-axis. (CTuB4, V. Petrov, et al.)

きな複屈折率と近赤外から真空紫外にわたる広い透過領 域を有するため, 真空紫外域での波長変換が可能となる.

ドイツのKaiserslautern大学からCLBOを使った266nmの 紫外光励起OPOの報告があった $(\mathrm{CMG1})$. 発表では励起用 紫外光源の開発にも触れており, 基本波光源として, LD励 起Nd: $\mathrm{YVO}_{4}$ レーザー (7ps, 82MHz, 27.4W)を用いて, LBO $(25 \mathrm{~mm}), \mathrm{CLBO}(10 \mathrm{~mm})$ からそれぞれ第2, 第4高調波を発生 させている。 それぞれ71\%,49\%の高い変換効率で, $7.9 \mathrm{~W} の$ $266 \mathrm{~nm}$ 光を得ている。出力の安定性は $4.7 \mathrm{~W}$ 时, 2 時間以上の 測定で4\%以下である.この光源を用いて $10 \mathrm{~mm}$ のCLBOか らのOPO実験を行っている. 結晶中での励起光のウォー クオフを避けるために, 入射方向を共振方向から 3 ずらし ている．442-480nmと597-668nmの可視領域でのチューニ ングが可能で, $135 \mathrm{~mW}$ の励起光に対して $26 \mathrm{~mW}$ のシグナル 光を得ている.

同じグループからBBOのOPO とその第2高調波発生の報 告もなされた (CTuB5). 励起光源はNd:YAGレーザー $(1 \mathrm{kHz}, 11 \mathrm{~ns}, 8.5 \mathrm{~W})$ の第3高調波で,2つのLBO結晶を用いて $3.2 \mathrm{~W}$ の紫外光を発生させている. type-IIのBBO $(7 \times 5 \times$ $0.5 \mathrm{~mm})$ を利用してOPOを行い, スペクトル幅の狭い $(4$ $\left.\mathrm{cm}^{-1}\right), 400-710 \mathrm{~nm}$ の光を得ている. OPOの光からBBOで第 2高調波発生を行い, 205-355nmの連続波長可变を実現して いる (Fig.25). この光源は分光や大気の微量ガスの検知に 十分利用できるとのことである。

三菱電機の小島らは, 高出力高繰り返し全固体紫外レー ザーの報告を行った (CTuB6)。自社開発のQスイッチLD 励起Nd:YAGレーザーからの第2高調波100W $\left(10 \mathrm{kHz}, \mathrm{M}^{2}\right.$ ～ 8) を基本光源に使用している. 第4高調波 $(266 \mathrm{~nm})$ の発生 には $140^{\circ} \mathrm{C}$ に加熱した長さ $15 \mathrm{~mm}$ のCLBOを用い, $20.5 \mathrm{~W}$ 高 出力紫外光を得ている (Fig.26). この時の変換効率は 19.4\%,パルス幅は46nsであった，CLBO素子の寿命につい ては現在調査中とのことであった。

ウシオ電機の大迫からは, CLBO結晶の特性と応用につ いて招待講演があった $(\mathrm{CTuB} 7)$. 講演内容はこれまでに取 り組んできた, $\mathrm{ArF}$ エシマレーザー $(193 \mathrm{~nm})$ 代替用全固体 光源の開発が中心であった. 最近のトピックスとしては, 


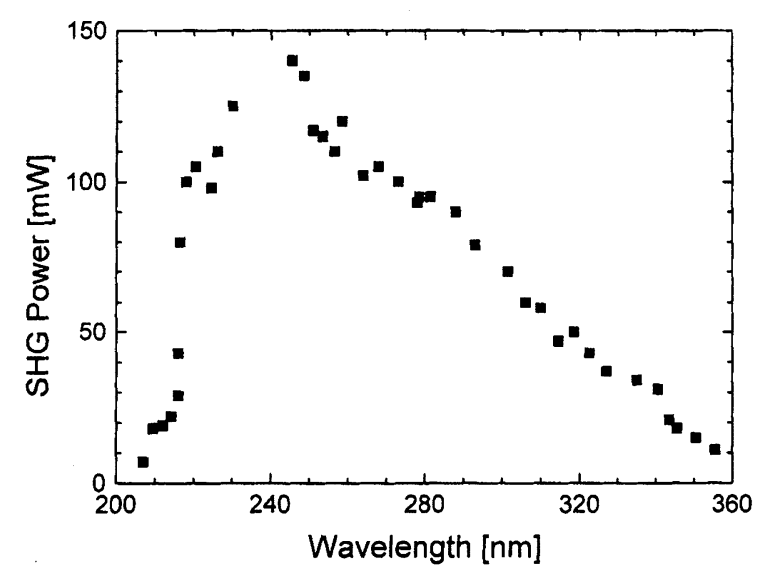

Fig.25 UV output power of the frequency doubled signal radiation of the BBO OPO pumped with $2.7 \mathrm{~W}$ of $355 \mathrm{~nm}$ pump radiation. (CTuB5, M. Peltz, et al.)

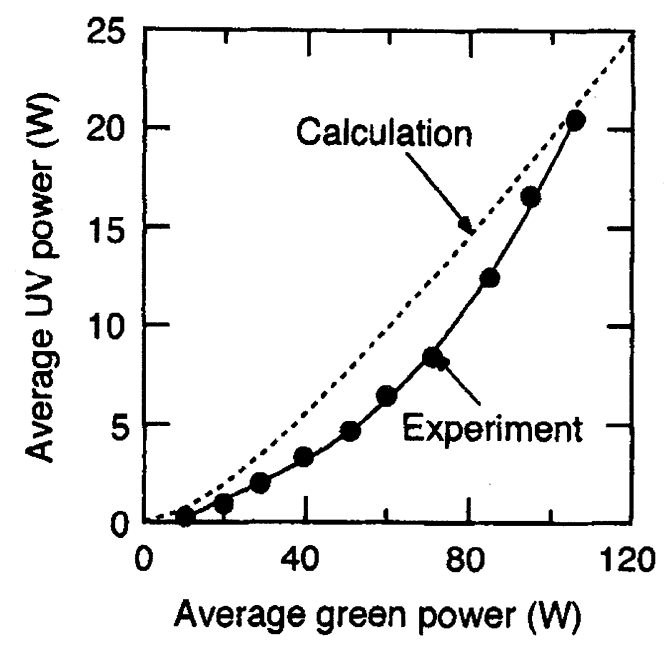

Fig.26 Average UV output power as a function of average green input power. (CTuB6, T. Kojima, et al.)

$1 \mathrm{~W}, 5 \mathrm{kHz}$ の196nm紫外光発生が挙げられる. システムは Nd:YLFのMOPA と, Ti:sapphire, 5つの波長変換ステージか ら構成されている. 可視,近紫外光への変換にはLBOを, 紫 外光の発生にはCLBOを用いている. Nd:YLF $(1047 \mathrm{~nm})$ の 第3高調波とTi:sapphire $(785 \mathrm{~nm})$ の和周波によって $241.6 \mathrm{~nm}$ 光を発生させ, Nd:YLFの残留基本波との和周波によって 1Wの196.3nmを発生させている。高出力が得られた理由
として, 強い残留基本波(15W)を利用し, 最終段のCLBOを 非臨界位相整合条件で使用したことなどが考えられてい る.

千歳科学技術大学の高岡らは, $\mathrm{AgGa}_{1-x} \mathrm{In}_{x} \mathrm{Se}_{2}$ 結晶 $(x=$ 0.474)による非臨界位相整合条件での $\mathrm{CO}_{2}$ レーザーの第3 高調波発生について報告を行った(CWF57)。この結晶は

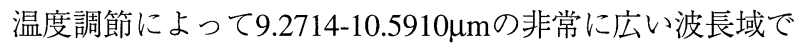
非臨界位相整合することが明らかになった。精度の良い 屈折率波長分散式(セルマイヤー方程式)や組成分散式につ いても発表があった。

中国のChenらのグループからは $\mathrm{K}_{2} \mathrm{Al}_{2} \mathrm{~B}_{2} \mathrm{O}_{7}(\mathrm{KAB})$ 結晶の 講演が予定されていたが，今回はキャンセルであった (CFF1).ダイジェストでは, Nd:YAGレーザーの第2, 第4 高調波の発生が可能なことが確認されている。阪大の著 者らのグループは, $\mathrm{Gd}_{x} \mathrm{Y}_{1-x} \mathrm{Ca}_{4} \mathrm{O}\left(\mathrm{BO}_{3}\right)_{3}(\mathrm{GdYCOB})$ 結晶の紫 外光によるグレイトラック損傷の発生と, 結晶加熱による 改善策について報告した (CFF2)。また, CLBO表面の耐 レーザー損傷性の向上についての報告も行った (CFF6).

Arイオンビームのエッチングによって, 光学研磨工程で埋 没した研磨剤を除去し, 紫外光 $(266 \mathrm{~nm})$ に対する素子寿命 を改善している。

GdCOB采結晶については, 他に5件の発表があり，レー ザー媒質をドープしたときの発振特性やセルフダブリン グについての報告であった。 全般的に, レーザー発振はYb: $\mathrm{GdCOB}$ の効率 $77 \%$ (CThJ5, フランス)のような高効率の特 性が得られるが, セルフダブリングの変換効率を高くする ことは難しいようである。単一素子としての魅力は持つ ものの, 実用レベルの光源にするには更なる改良が必要で ある.フランスのAugéらはNd:GdCOBのマイクロチップ グリーンレーザー (共振器長5～8mm) の開発を試みたり, 自己和周波発生 $(1090+812 \rightarrow 465 \mathrm{~nm})$ によるブルー光発生 についての研究も行っている(CFF3).

(吉村 政志)

\section{7. 高出カレーザー}

Table 1に連続発振およびロングパルス動作における高 出力レーザーの報告結果をまとめて示す. Yb:YAGで1kW 以上, $\mathrm{Nd}: \mathrm{YAG} て ゙ 3 \mathrm{~kW}$ 以上の高平均出力動作が報告され た. Yb:YAGの高出力動作に関しては, ローレンスリバモ

Table 1 High average power solid state lasers.

\begin{tabular}{|c|c|c|c|c|c|c|c|}
\hline 媒質 & 波長 ( $\mu \mathrm{m})$ & 出力 & 効率 (光－光) & ビーム品質 & 講演番号 & 研究機関 & 特長 \\
\hline $\mathrm{Yb}: \mathrm{YAG}$ & 1.03 & $1.08 \mathrm{~kW}(\mathrm{CW})$ & $27.5 \%$ & $\mathrm{M}^{2}=13.5$ & CMF2 & LLNL & 2rod補償 \\
\hline \multirow[t]{5}{*}{ Nd:YAG } & 1.06 & $3.3 \mathrm{~kW}$ (平均) & $35 \%$ & $\mathrm{M}^{2} \sim 185$ & CMF5 & 東芝 & ロッド \\
\hline & & $3.6 \mathrm{~kW}$ (平均) & - & $\mathrm{M}^{2} \sim 3.5$ & LTuB3 & TRW & スラブ \\
\hline & & $1 \sim 3 \mathrm{~kW}(\mathrm{CW})$ & - & $\mathrm{M}^{2} \sim 36$ & LTuB2 & Rofin-Sinar社 & 販売ベース \\
\hline & & $120 \mathrm{~W}(\mathrm{CW})$ & $51 \%$ slope & $\mathrm{M}^{2} \sim 30$ & CMF6 & Stanford大 & 伝導冷却スラブ \\
\hline & & $65 \mathrm{~W}(\mathrm{CW})$ & $43 \%$ & $\mathrm{M}^{2} \sim 1.7$ & CMF3 & Stuttgart & ディスク \\
\hline Nd:YLF & 1.05 & $100 \mathrm{~W}$ (平均) & $33 \%$ & $M^{2} \sim 10$ & CMF7 & 三菱電機 & 伝導冷却ロッド \\
\hline \multirow[t]{2}{*}{$\mathrm{Nd}: \mathrm{YVO}_{4}$} & 1.06 & $53.5 \mathrm{~W}(\mathrm{CW})$ & $27 \%$ & $\mathrm{M}^{2} \sim 1.7 \times 1.2$ & CPD1 & Q-peak Incorporated & 側面励起 \\
\hline & 1.34 & $24.5 \mathrm{~W}(\mathrm{CW})$ & $12 \%$ & $\mathrm{M}^{2} \sim 1.2 \times 1.2$ & & & MOPA \\
\hline $\mathrm{Yb}$ fiber & 1.12 & $110 \mathrm{~W}(\mathrm{CW})$ & $58 \%$ & $\mathrm{M}^{2} \sim 1.1$ & CPD11 & SDL. Inc. & 2重クラッド \\
\hline
\end{tabular}


ア国立研究所のE. C. Honeaらから1件報告された (CMF2). このグループではこれまでホロー型のレンズダクトを用 いた共振器内に配置可能な端面励起型Yb:YAGロッド $\left(2 \mathrm{~mm}^{\phi}\right)$ を1本用いた高出力レーザーの報告を行なっている が, 今回2本のロッドを用いロッド間に旋光子を配置する熱 複レンズの補償(熱複屈折の補償と等価)を行なうことで, 出力 $1080 \mathrm{~W}, \mathrm{M}^{2} 13.5$ という高出力, 高輝度化を達成した. また, 1本のロッドによる低パワー時の熱複屈折補償法とし て,昨年サザンプトン大から提案された $1 / 4$ 波長板を用いる

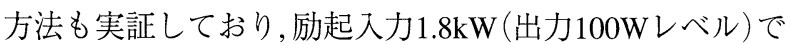
も効果があることが示された。一方, $\mathrm{Nd}: \mathrm{YAG} の$ 高出力動 作に関しては, 東芝の高瀬らからロッドレーザーを用いた 出力 $3.3 \mathrm{~kW}$ のレザーが報告された(CMF5)。ここでは, 励 起を行なうLDアレーのスロー軸方向をロッド軸と垂直に 配置し, 励起光のフローチューブに対する透過率を改善し, ファースト軸方向をロッド軸と垂直に配置した従来に比 ベ高い励起効率を実現している．この他にもレーザー加 工のセッションで, 日米欧でそれぞれ行なわれているレー ザー加工プロジェクトにおけるNd:YAGレーザーの高出力

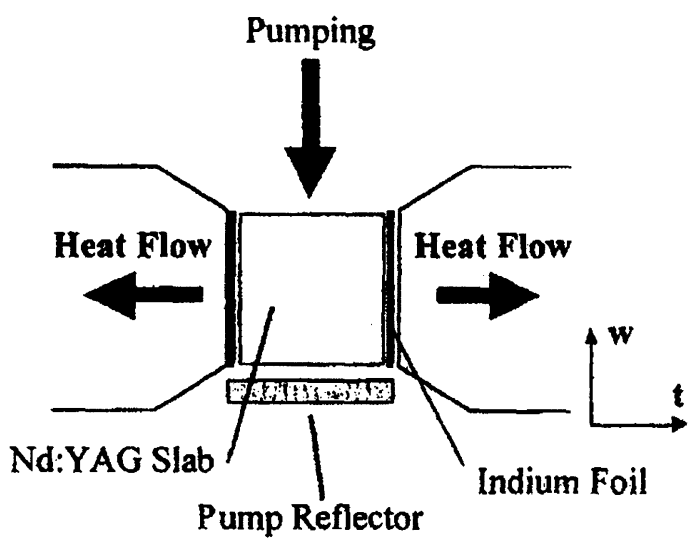

Fig.27 Cross-sectional view of the edge-pumped slab laser geometry. The conductively-cooled slab is clamped in a water-cooled aluminum housing. Double-pass pumping is provided by a difuse reflector below the slab. Indium foil is used to ensure a uniform contact between the Nd:YAG slab and the cooling surface. (CMF6, T. S. Rutherford, et al.)
動作が報告され, 各プロジェクトの成果としてそれぞれで $3 \mathrm{~kW}$ 以上出力が報告された。 特に, TRW社のスラブレー ザーでは, 出力 $3.6 \mathrm{~kW}$ で $\mathrm{M}^{2}$ が3.5という高出力, 高輝度動作 が実現されている (LTuB3)。Yb:YAGとNd:YAGの比較と いう点では, MITのT. Y. Fanが招待講演 (CMF1)で, 概ねの 高出力レーザー用途 (出力 $<10 \mathrm{~kW}$ )においては, Nd:YAGが $\mathrm{Yb}: \mathrm{YAG}$ に比べて優れた特性が得られるだろうとの知見を 述べたのが印象的であった。

これらの固体レーザーの出力限界に向けての高出力競 争以外では, 伝導冷却方式による高出力レーザーがスタン フォード大学，三菱電機から報告され，伝導冷却による $100 \mathrm{~W}$ 以上の平均出力がそれぞれ報告された. Fig.27に, ス タンフォード大のT. S. Rutherfordらから報告された励起構 成を示す (CMF6). Nd:YAGスラブのジグザグ伝搬の反射 面をコーティングにより形成し，このコーティング面を金 属面に熱伝導させ熱を奪っている。一方, 励起光は入射開 口の小さいファイバとし, これ以外の面を反射面とするこ とで, 励起光をスラブ内に閉じ込め高励起効率を得てい る。一方,ロッドを用いた三菱電機の柳澤らから報告され た(CMF7) 励起構成をFig.28に示す. Nd:YLFロッドの周り に熱伝導率の高い $\mathrm{MgO}$ ブロックを薄い液体層を介して熱 接触させ, 熱拡散器として用い, $\mathrm{MgO}$ ブロックの広い面積 を持つ側面から放熱することで冷却パスの熱抵抗を減じ ている。また, $\mathrm{MgO}$ ブロックの周りに反射コートを施し, 励起光を閉じ达める構成で励起効率の向上を図ってい る.

$\mathrm{Nd}: \mathrm{YAG}$ では, 100Wクラスのレーザーが数多く報告され るようになってきたが, これ以外の媒質においての高出力 化も進んでいる.Nd:YLFでは, 前述の三菱電機が2ロッド で100W以上, $\mathrm{Nd}: \mathrm{YVO}_{4}$ では, MOPA構成 (5ロッド)で50W以 上, 2 ロッドを用いた発振器で35Wの高出力動作が報告され た. Fig.29に, ポストデッドラインペーパーでQ-Peak IncorporatedのK. J. Snellらから報告されたNd: $\mathrm{YVO}_{4}$ のMOPA構 成を示す (CPD1). 側面励起されたロッド内をビームをず らしながら複数回レーザー光を通過させて空間的な励起 分布とレーザー光の重なりを大きくする励起へッドを5個 用いている。一方, Fig.30は, Spectra-Physics社のW. L. Nighanらから報告されたNd: $\mathrm{YVO}_{4}$ の発振器構成である

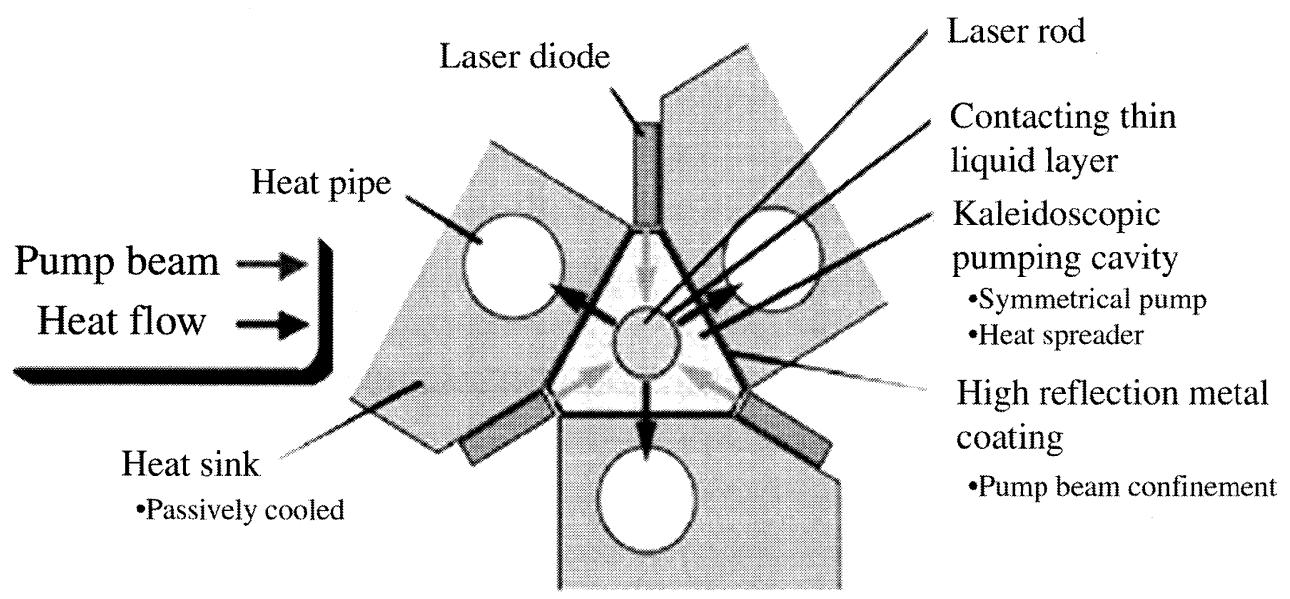

Fig.28 Cross sectional view of conductive-cooled Nd:YLF rod laser. (CMF7, T. Yanagisawa, et al.) 


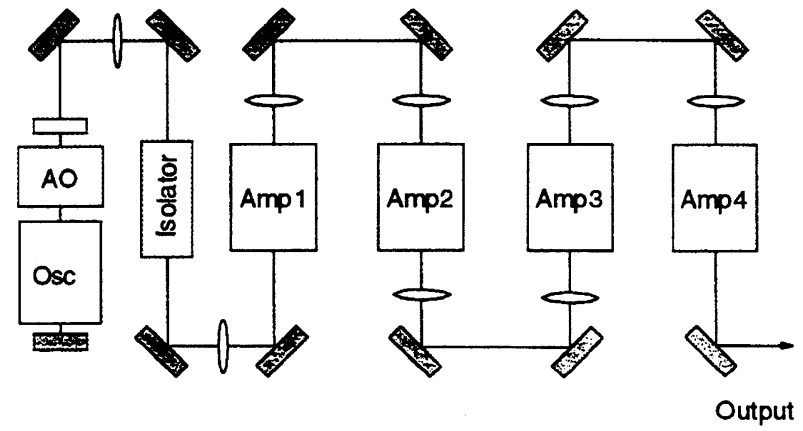

Fig.29 Schematic of the five gain module $\mathrm{Nd}: \mathrm{YVO}_{4} \mathrm{MOPA}$ system. (CPD1, Kevin J. Snell, et al.)

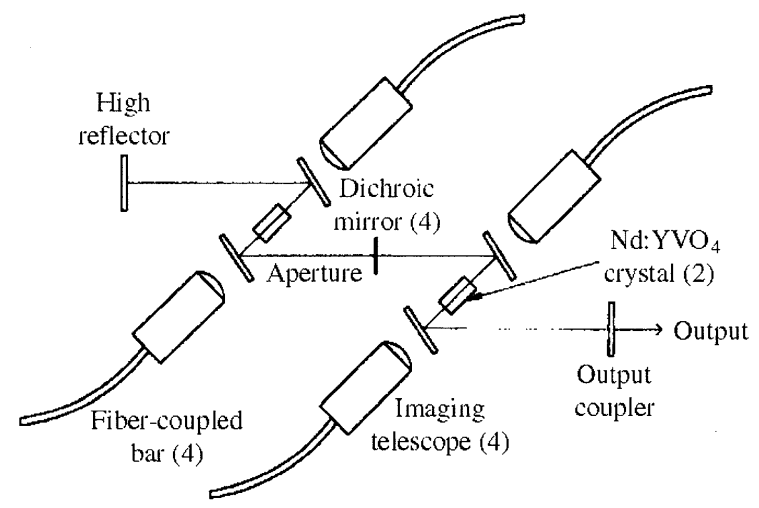

Fig.30 Configuration of the fiber-coupled diode-barpumped $\mathrm{Nd}: \mathrm{YVO}_{4}$ laser. A periodic resonator is employed utlilizing two " $\mathrm{Z}$ " building blocks. The total length is $\sim 50 \mathrm{~cm}$. (CMA1, William L. Nighan, et al.)

(CMA1). 15Wのファイバ出力励起光を4本用いて, 2本の ロッドを両端面励起している，端面励起においては, 熱収 差による回折損失がTEM $\mathrm{T}_{00}$ モード出力を劣化させることが 知られているが, ロッド中心に均一励起部分を作り, 励起 部分よりレーザービーム径を小さくすることで熱収差の 影響を減じ, 取り出し効率94\%で35Wの出力を得ている.

結晶材料では無いが, ポストデッドラインペーパーで報 告された2重クラッドYbファイバレーザーでの出力 $110 \mathrm{~W}$, 効率58\%の横基本モード発振は, 今回のCLEOにおけるト
ピックスの一つである. Fig.31は, SDL社のV. Dominicらか ら報告されたファイバレーザーの構成である (CPD11)。出 力45Wの高輝度励起光を偏波合成し, 両端面励起する構成 で180Wの励起光を, $\mathrm{Yb}$ ファイバの $170 \mu \mathrm{m} \times 300 \mu \mathrm{m}$ の矩形 クラッドに入射している。共振器は,ファイバ端面におか れた励起光透過でレーザー光反射のダイクロイックミ ラー(DM1)と,クリーブされた他端 (反射率〜 4\%) で構成し ている，驚いたことにシングルモードのコア径は $9.2 \mu \mathrm{m} て ゙$, 出力端面におけるパワー密度は連続波で $300 \mathrm{MW} / \mathrm{cm}^{2}$ 以上 にもなっている換算となる，ファイバレーザーに関して は, レーザー加工のセッションで, 日本のレーザープロジェ クト(フォトン計測・加工プロジェクト)において開発中の $\mathrm{kW}$ クスの側面励起型であるディスクファイバレーザー には多くの感心が寄せられるとともに, ポストデッドライ ンペーパーで, サザンプトン大のA. B. Grudininからやはり 側面励起型が報告され(CPD26), 今後, ファイバレーザー が本当の意味で固体レーザーに競合する高出力レーザー となっていくことを実感した。

高平均出力動作に対して,レーザー加工や高効率波長変 換をターゲットに, 高ピーク出力化の報告も数多くなされ ている. Table 2にQスイッチパルス動作における高出力 レーザーの報告結果をまとめて示す．Fig.32は三菱電機の 平野らから報告された $(\mathrm{CMF} 4)$ 高平均出力, 高ピーク出力,

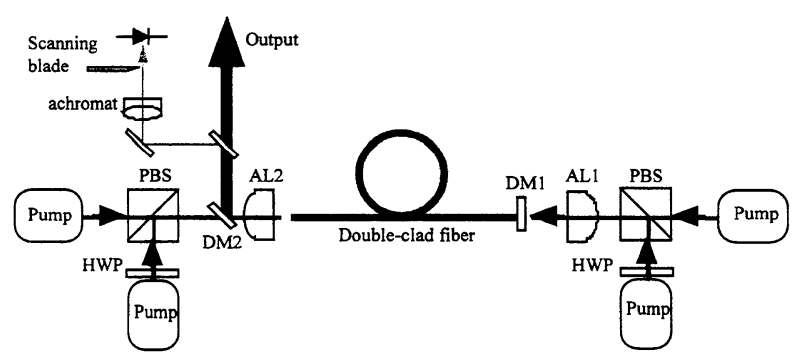

Fig.31 Layout for the high power fiber laser. The acronyms are: PBS-polarization beam splitters, HWPzero-order half-wave plates, AL-aspheric lenses, and DM- dichroic mirrors. The upper left hand corner shows the lens and razor edge used for the $\mathrm{M}^{2}$ beam quality measurements. (CPD11, V. Dominic, et al.)

Table 2 High average power Q-switched solid state lasers.

\begin{tabular}{|c|c|c|c|c|c|c|c|c|}
\hline 媒質 & 波長 $(\mu \mathrm{m})$ & 平均出力 & パルス幅(ns) & ピーク出力 & ビーム品質 & 講演番号 & 研究機関 & 特長 \\
\hline Yb:YAG & 1.03 & $183 \mathrm{~W} / 5 \mathrm{kHz}$ & $73 \mathrm{~ns}$ & $500 \mathrm{~kW}$ & $\mathrm{M}^{2}=2.4$ & CMF2 & LLNL & - \\
\hline \multirow[t]{3}{*}{ Nd:YAG } & 1.06 & $\begin{array}{c}230 \mathrm{~W} / 32 \mathrm{kHz} \\
8 \mathrm{kpps}\end{array}$ & $32 \mathrm{~ns}$ & $900 \mathrm{~kW}$ & $\mathrm{M}^{2}=1.6$ & CMF4 & 三菱電機 & $\begin{array}{c}\text { QCW励起 } \\
\text { ロッド }\end{array}$ \\
\hline & & $550 \mathrm{~W} / 5 \mathrm{kHz}$ & $150 \mathrm{~ns}$ & $700 \mathrm{~kW}$ & $\mathrm{M}^{2} \sim 3$ & LTuB3 & TRW & $\begin{array}{c}\text { CW励起 } \\
\text { スラブ }\end{array}$ \\
\hline & & $1.25 \mathrm{~kW}$ & - & $2.5 \mathrm{MW}$ & $\mathrm{M}^{2} \sim 7$ & LTuB3 & $\begin{array}{c}\text { GE } \\
\text { FiberTek }\end{array}$ & MOPA \\
\hline Nd:YLF & 1.05 & $50 \mathrm{~W} / 150 \mathrm{~Hz}$ & $36 n s$ & $9.3 \mathrm{MW}$ & $\mathrm{M}^{2} \sim 2.5$ & CMF7 & 三菱電機 & $\begin{array}{c}\text { 伝導冷却ロッド } \\
\text { MOPA }\end{array}$ \\
\hline $\mathrm{Nd}: \mathrm{YVO}_{4}$ & $\begin{array}{l}1.06 \\
1.34\end{array}$ & $\begin{array}{l}50.7 \mathrm{~W} / 50 \mathrm{kHz} \\
23.5 \mathrm{~W} / 50 \mathrm{kHz}\end{array}$ & $\begin{array}{l}10 \mathrm{~ns} \\
28 \mathrm{~ns}\end{array}$ & $\begin{array}{c}101 \mathrm{~kW} \\
17 \mathrm{~kW}\end{array}$ & $\begin{array}{l}\mathrm{M}^{2} \sim 1.7 \times 1.2 \\
\mathrm{M}^{2} \sim 1.2 \times 1.2\end{array}$ & CMF7 & $\begin{array}{c}\text { Q-peak } \\
\text { Incorporated }\end{array}$ & $\begin{array}{c}\text { 側面励起 } \\
\text { MOPA }\end{array}$ \\
\hline
\end{tabular}




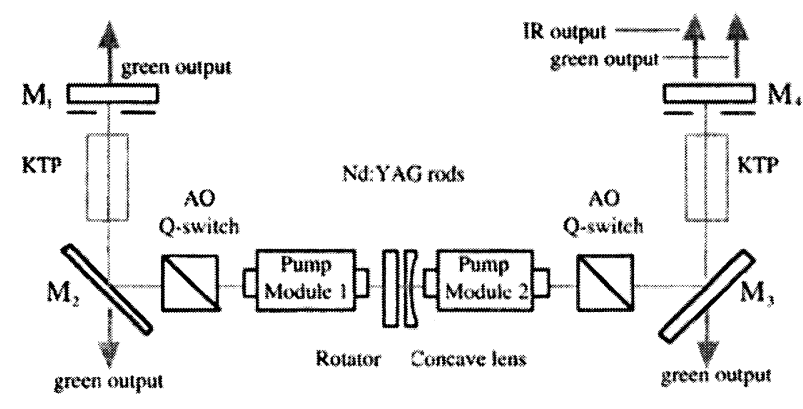

Fig.32 The experimental set-up used for Q-switch and green generation. (CMF4, Y. Hirano, et al.)

高輝度を目指したNd:YAGレーザーの構成である，Qス イッチ動作において高効率を得る高繰返し条件において, 低熱負荷条件でレーザー媒質の利得をあげ高ピーク出力 (短パルス幅)を得るために, 励起LDとしてQ-CW LDを用 い, 平均出力 $220 \mathrm{~W}$, ピーク出力 $0.9 \mathrm{MW}, \mathrm{M}^{2} 1.6$ を得ている.

(平野嘉仁)

\section{8. 原子光学}

量子エレクトロニクスおよびレーザー分光の基礎分野 では近年中性原子のレーザー冷却とそれを用いたボー ズ・アインシュタイン凝縮の研究が非常に注目を集めて いる.ここ数回のCLEO/QELSやIQECでも常にホットな研 究成果が報告されてきた. 今回のQELSのオーラルセッ ションとして, ボーズ凝縮のセッション 2 つ, 原子光学, 光 格子等がもうけられた. 原子光学関係の口頭発表は33件 で内9件が招待講演であった。ポスターは12件であった。 論文数はやや少な目であったし, 実験の最前線の報告も少 なかったように思う。この分野の研究者のメインの発表 の場がAPSのMarch Meetingや原子分光国際会議などに 移っているのではないかと思われる。ポストデッドライ ンセッションでも原子光学関係の発表は2件のみであっ た。ポストデッドライン論文の一つは東大のグループに よるもので昨年末に本邦初のボーズ凝縮を実現したグ ループからの干渉実験の報告であった。これについては 後で詳しく触れる。ここでは, 今回の会議の講演の中から いくつか重要な成果について以下に紹介する。

まずボーズ凝縮のセッションの最初の講演はMITの Kleppnerによる小素のボーズ凝綃に関する報告(題名は "Observation of Bose-Einstein condensation in atomic hydrogen by laser spectroscopy”)であった。水素のボーズ凝縮の 実現には実に22年を要しついに昨年の8月に成功した。水 素原子という最も単純な原子でのボーズ・アインシュ夕 イン凝縮の実現は既に実現されているアルカリ原子とは また違った意味合いのある歴史的な大きな業績であると 感じた．講演では水素のボーズ凝縮に至る過程に加え, 分 光学的に凝縮原子をどのように観測するかということに ついて詳しい説明が行われた。ボーズ凝縮の観測には1S$2 \mathrm{~S}$ の光子遷移が用いられた。ボーズ凝縮の観測には原子 の密度の測定が必須である。ここでは原子密度に依存し た共鳴のシフトをkHzオーダーで精密に捉えることで非常
に定量的に密度を評価できることが示された。これは紫 外領域での高精度の分光技術に基づくもので, 今世紀後半 でのレーザー分光技術の集大成ともいえるものである. ボーズアインシュタイン凝縮した水素原子はアルカリ原 子の場合とはかなり違ったパラメー夕領域にある。原子 数は $10^{9}$ と桁違いに大きいし, 温度は $40 \mu \mathrm{K}$ 程度であり, アル カリ原子のサブ $\mu \mathrm{K}$ とは大きく異なる。この意味で水素の ボーズ・アインシュタイン凝縮の実現は低温物理学に新 たなインパクトをもたらすことは間違いなく, 今後の展開 が楽しみである，尚実現に至るまでの解説はPhysics Today 51 (邦訳パリティー 14 (1999) 43)にある.

ボーズ凝縮セッションのつづいての実験報告はワシン トンNISTのW. D. Phillipsらのグループから行われた(題名 は“Atom optics with Bose-Einstein condensation”)．彼等の グループは昨年1月にナトリウム原子のボーズ凝縮に成功 して以来, 光定在波とボーズ凝縮体との相互作用に関する 数多くの精力的な研究をすすめてきている. 今回の発表 はその総合報告ともいえるもので, ボーズ凝縮体のコヒー レント回折現象に始まり，それを利用した高指向性原子 レーザーの開発, 非線形原子波光学の実現といった全く新 しい研究分野の開拓がなされた. 発表時間の関係で報告 はされなかったが, 彼等のグループは原子レーザーのコ ヒーレント長の測定にもすでに成功している，グループ はまず生成したナトリウムのボーズ凝縮体に短時間光定 在波を照射することで原子を回折させ, 凝縮体を空間的に 複数個に分裂させた。これは定在波を形成している対向 するレーザー光によって異なる運動量状態間の誘導ラマ ン遷移が引き起こされ, 原子が光子反跳運動量をうけとっ た結果と解釈するとわかりやすい。ボーズ凝縮体は $10 \mu \mathrm{m}$ 程度の長距離にわたってコヒーレンスを維持しているた め, 光定在波を照射することは acシュタルク効果によって 周期的位相分布を原子波動関数にマッピングすることと 同じである。したがってこの実験は一種の原子ホログラ フィーであると彼等のグループは主張していた。位相を マップした結果が単なる回折だということで，ホログラ フィーという言葉に抵抗を感じる者もあるかとは思うが, 彼等はこの技術を延長してソリトンやボアテクスを生成 することまで考えており,ホログラフィーという一般化さ れた概念に基づいて系統的に研究を進めるやりかたには うならされる。

彼等は次のステージとして, 進行定在波を凝縮体に照射 した場合に起こる共鳴回折現象を観察した。定在波をあ る一定の速度で進行させると, 原子の分散関係によって決 まる共鳴条件がみたされ, その結果として原子に対して決 められた方向に決められた運動量を与えることが可能と なる. 先程の回折に対して, 共鳴ブラッグ回折を起こした と考えるとわかりやすい。この高い指向性に着目して, 彼 等は磁場トラップ中のボーズ凝縮体をブラッグ回折させ ることで原子レーザーを実現することを考えた，進行定 在波を形成する二つのレーザー光の偏光と差周波数を制 御することで, 原子の回折と同時に原子のスピン状態まで をも変化させ,磁場トラップから好きな方向に原子を解放 しコヒーレントな原子ビームを作ることに成功した。原 
子レーザーは現在MIT Ketterleグループ, Max-Planck Hansch グループ, Yale Kasevichグループ, そしてNIST Phillipsグ ループの計 4 グループで成功しているが, 原子の出射方向と 運動量とを重力とは無関係に自由にかつ正確に制御でき るタイプの原子レーザーはNISTグループのもののみであ る. 原子レーザーを用いて干涉計を組み, 重力測定をおこ なったりジャイロを構築するといったことを行う際, 原子 レーザーの出射方向を自由に変えられるということが本 質的な意味を持ってくる。 また彼等の実験では, 磁場卜 ラップ中の凝縮体からわずかずつ原子が光反跳運動量を うけとって射出される。このような条件下では, 磁場卜 ラップ中で蓄えられたmean-field斥力相互作用が空間的に 等方的に解放されず, 原子が射出された方向に集中的に解 放される，そのため, 原子レーザーの断面方向の運動量幅

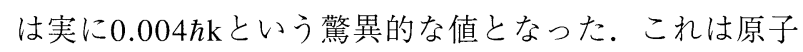
レーザーの広がり角度として数mradに対応し, 商品化され ている光レーザーのそれとほぼ同じ性能を与える。なお ブラッグ回折に関する解説はM. Kozuma et al.: Phys. Rev. Lett. 82 (1999) 871に, 原子レーザーに関する解説はE. W. Hagley et al.: Science 283 (1999) 1706に詳しい.

彼等の次なる実験ステージは,こうした高い指向性を持 つコヒーレント原子波束を利用して, 光でいうところの非 線形光学,つまり非線形原子波光学を実現しょうというも のであった。具体的には4原子波混合を実現した．光を用 いて4光波混合を行う際には媒体が3次の非線形性を持つ ことが必要となる。彼等は凝縮体の高密度性から生じる mean-field相互作用を3次の非線形として利用することを考 えついた。これは次のように考えるとわかりやすい。二 つの原子波束が対向方向から枑いにぶつかりあったと する。波束間にコヒーレンスがあれば, 波動関数が互いに 干渉することで, 原子波束が重なった領域に周期的な原子 密度分布の変化が生じる。つまり原子回折格子が形成さ れる。ここに3番目の原子波束を入射させたとしょう。通 常の冷却原子のように原子密度が低ければ, 3 番目の原子波 束は何もなかったかのようにこの原子回折格子を素通り してしまう。しかしボーズ凝縮体のように密度が高いと, 原子回折格子に扮いて原子密度の高い部分ではmean-field 斥力相互作用が強くなり, そこに入射した原子波は周期的 な斥力ポテンシャルを感じることになる。そのため原子 波の回折が生じ,4番目の波束がうまれることとなる. 彼等 はボーズ凝縮体をブラッグ回折させることで,3つの異なる 運動量を持つ原子波束を生成し互いに混ぜあわせた．波 束の運動量と進行方向は位相整合条件をみたすようにあ わせられた。そ結果, 4番目の波束が理論と一致する方向 と運動量で射出されるのを観測した。彼等のグループは, 同様の手法を用いてSHGや6原子波混合などを行うことも 考えたようである。しかしながら原子系を用いた場合に はその対称性ゆえにSHGを行うことは残念ながらできな い.また6原子波混合を行うには,グロスピタエフスキー方 程式でサポートされる以上の高次の項の寄与を期待しな ければならないが,このような高次の項の影響がでるとし たらかなりの高密度のボーズ凝縮体が必要となる。しか しそのような高密度状態では3体衝突が起こって凝縮相自
体が維持されなくなってしまうため,これもまた観察が難 しいようである。なお4原子波混合に関する解説はL. Deng et al: Nature 398 (1999) 218に詳しい.

ボーズ凝縮に関する実験報告として最後に, 昨年12月に $\mathrm{Rb}$ のボーズ凝縮に成功した日本の久我グループによるも のを紹介したい。この結果はポストデッドラインに発表 された。題目は(“Atom wave interferometer for a BoseEinstein condensate with Bragg diffraction”)であった。彼等 はNISTグループによって開発されたブラッグ回折の技術 を利用して $100 \%$ のントラストを持つマッハッェンダー 原子波干渉系を構成した。ボーズ凝縮を一回生成するの にかかる時間は,グループによってもまちまちだが, 数十 秒から数分程度である。したがって原子ビームの場合と 異なり, ボーズ凝縮体を利用した干渉計では, 原理的に考 えて干渉プロットを作成するのに膨大な時間がかかって しまう。そのため利用価值が少ないと考えがちだが, 彼等 のグループは従来の原子干渉計の延長としてこの方法を 評価しているわけではなかった。この干渉計を利用する ことで凝縮体の空間位相分布といった,これまで検出が難 しかった物理特性の観察が可能となるというのが彼等の グループの主旨であった．アルカリ原子のボーズ凝縮体 が持つ物理的特性のほとんどは, 光吸収 2 次元イメージから 測定される。しかしボーズ凝縮体の大きさが $10 \mu \mathrm{m}$ 程度と 非常に小さいこと, そしてイメージングの空間分解能が数 ミクロンしかないことから,すべての情報を単なる吸収イ メージから得ようとすることには限界がある。例えばボ アテクスの持つ角運動量などは, ボアテクスの核の大きさ が小さいために通常のイメージングでは検出が困難であ る。しかし干渉を利用することで情報をイメージングの 分解能内の空間構造にやきなおし, 定量的にかつ正確に測 定することが可能と久我グループでは考えている.

彼等の干渉計の原理は次のようになっていた。ブラッ グ回折では進行定在波を照射する時間をコントロールす ることで, 運動量0の状態から運動量 $2 \hbar \mathrm{k}$ の状態へと回折さ れる原子のポピュレーションを自由に調整することがで きる. 彼等は, 照射時間の異なるブラッグ回折をミラーと

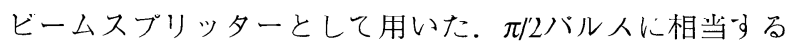
ブラッグ定在波をあてることで, 原子を 0 運動量と $2 \hbar \mathrm{k}$ 運動

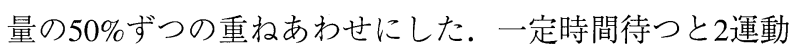
量状態は, それぞれの速度で空間的に分離していく．つぎ にルパルスをあてることで運動量を0から $2 \hbar \mathrm{k}, 2 \hbar \mathrm{k} か ら 0 へ$ と交換する. 分離された波束は再びお互いに近づきはじ める．完全に二つの波束が重なったところで, 最後にもう 一度 $\pi / 2$ パルスをあてることで, 原子をもとの0運動量状態 へと戻した。干渉計が実現されていることを確かめるに は, 最後に照射する $\pi / 2$ パルスの定在波の位相をずらしなが ら,2運動量状態のポピュレーションの変化をみればよい. 彼等は位相シフトにともなってポピュレーションが正弦 波的に変化することを観察することに成功した。

この 1,2 年の間に最も困難とされていたボーズ凝縮の実 験が世界的に普及してきた．現在のところ,これまでレー ザー冷却原子で行われてきた原子光学の実験を極限まで つきつめようという動きが主なようである。しかし原子 
光学は基本的に原子の持つ1次のコヒーレンスを利用した ものであり,これまでのレーザー冷却の歴史と同様の長い 時間,こうした研究が続くとは思えない.今後はボーズ凝 縮体を利用した量子コンピューティングなどといった， まったく新しい分野の開拓が急速になされていくのでは ないだろうか.

（五神 真, 上妻 幹男, 鳥井 寿夫）

\section{9. 超高速光電子デバイス}

CLEO'99における超高速光電子デバイスについて報告 する．関連する主なセッションは, (1) Ultrafast Opto-Electronics $(\mathrm{CTuL}),(2)$ Terahertz Optoelectronics (JThA), (3) Terahertz (JThC, JThD), (4) Photonic A/D Converters and Terminal Processing $(\mathrm{CtuN})$ である. 会議の傾向として, 高速光 通信に直結するデバイス・システムに関する発表は, OFC (Optical Fiber Conference) へと集約されて減少傾向にある が, 新たにTHz(テラヘルッ)に関する3つのセッションが QELSと共催されるなど, テラヘルツとその応用に関する研 究発表が大幅に増大した，本章では, $\mathrm{THz}$ の発生と検出, 高 速光スイッチング技術, デバイス応用について報告する.

\section{$9.1 \mathrm{THz}$ の発生と検出}

発生に関しては,応用を目指しての高輝度THz光源の研 究開発が進んでいる.Ping $\mathrm{Gu}$ (通信総合研究所)らのグ ループは, InSbからの光励起THzの0.23Tまでの磁場依存性 を測定した(Fig.33)。InSbは, InAsに対して約3倍の移動度 を有し電子の有効質量が約半分である。従って, ローレン ツ力による光励起キャリアの加速度が大きくなることか ら, 磁場印加時の $\mathrm{THz}$ 電磁波の放射強度の増大が顕著にな る、0.23Tの磁場を加えた時の放射強度は, InAsの場合の約 2倍であることが報告された. S. Izumida（分子科学研究所） らのグループからは, 磁場印加によるTHzスペクトル制御 の発表(JTHA4)において, 永久磁石を利用した手のひらサ

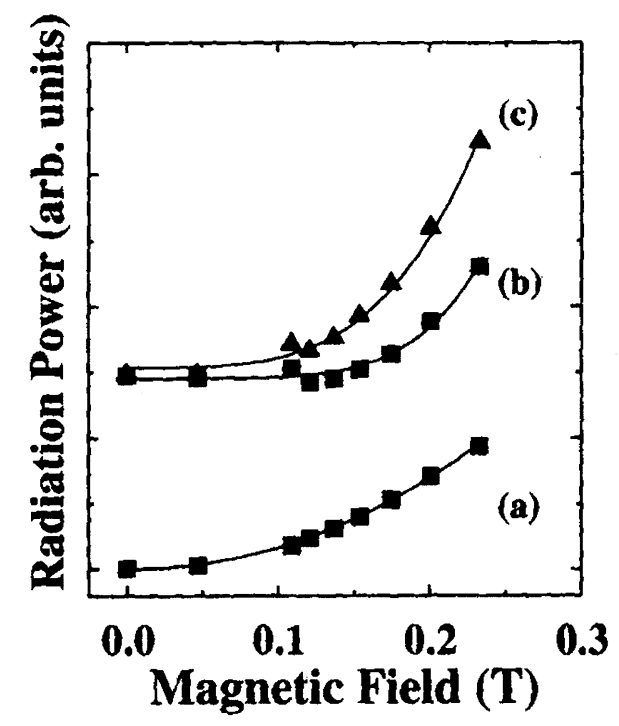

Fig.33 Magnetic field dependence of the radiation power for the horizontal (a) and vertical (b) components as well as the sum (c) of the two components. (JThA5, P. Gu, et al.)

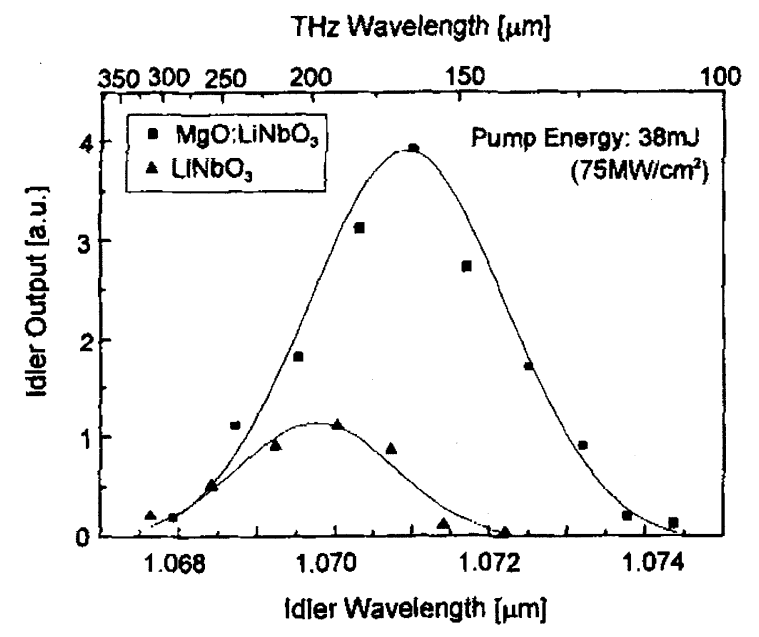

Fig.34 Measured output characteristics of idler waves from $\mathrm{LiNbO}_{3}$ and $\mathrm{MgO}: \mathrm{LiNbO}_{3}$ OPOs at a fixed pump energy $(38 \mathrm{~mJ})$. (CThuH1, J. Shikata, et al.)

イズの高輝度 $\mathrm{THz}$ 発生装置の紹介がなされた，手のひらサ イズにもかかわらず, 1T以上の磁場を実現しており, 小型 高輝度THz光源の実用化へ向けて大きく前進した。 J. Shikata (東北大学) らのグループは, $\mathrm{MgO}$ をドープすること により, $\mathrm{OPO} に よ る \mathrm{LiNbO}_{3}$ からのTHz電磁波の出力を4倍に まで高めることに成功した $(\mathrm{CTuH} 1)$ ）測定結果をFig.34に 示す．励起光の入射角度を調整することにより，0.9 3.0THzの波長可変のTHz光源を実現している.

検出に関しては, 簡便・高感度 ·高帯域という点から,チ タンサファイアレーザーとZnTe結晶を組み合わせた電気 光学サンプリング法による測定が様々なグループにより． 行われた. Q. Chen (Rensselaer Polytechnic Institute)らのグ ループは, 信号検出のための変調方式を強度変調から位相 変調にすることにより，2倍の信号強度の増大を得た (JThA2). 推定されるS/Nは30dB以上であり, 紙幣の透かし 認識への応用を行った(Fig.35)。一方, G. Gallot (Oklahoma State University)らのグループは, ZnTeの結晶厚さとカット オフ周波数のトレードオフについての講演を行った (JThD1)。測定結果の定量的な解析を行うためには, 結晶 のfilter functionを考慮する必要が有り, 5THz以上の測定に は結晶厚 $0.1 \mathrm{~mm}$ 以下が必要との計算結果が示された。

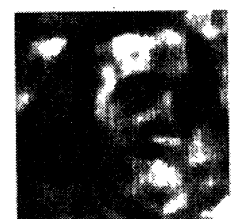

(a)

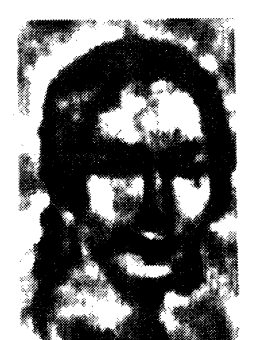

(b)

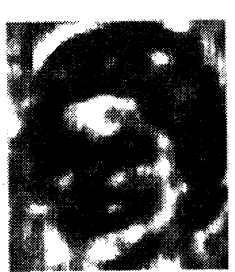

(c)
Fig.35 THz images of watermark in (a) 100 U. S. Dollar, (b) 100 Germany Mark, and (c) 20, British Pound. (JThA2, Q. Chen, et al.) 


\section{2 高速光スイッチング技術}

光スイッチング技術としては, R. Takahashi (NTT光エレ クトロニクス研究所) らのグループから, 完成度の高い光 · 光スイッチの発表がなされた $(\mathrm{CThF} 4)$. 素子の構成を Fig.36に示す。ベリリウムを添加したInGaAs量子井戸の キャリア再結合寿命がフェムト秒領域であることを利用 した光・光スイッチである. ポンプ光入射時の量子井戸 の高速可飽和吸収特性を利用して, シグナル光を切り出す ノーマリー・オフ型の光・光スイッチである。偏波無依

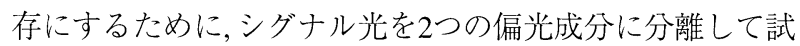

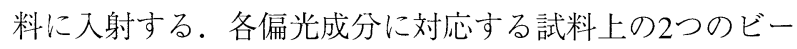
ムスポットに対して,光・光スイッチング動作を行った後, 両成分を合波して出力する。切り出されたシグナル光の パルス幅は300fsであり (Fig.37), ポンプ光エネルギー10pJ においてOn/Off比30dBが得られている。また, On/Off比が シグナル光の偏光状態によらず $30 \mathrm{~dB}$ が得られている. K. T. Hall(MITリンカーンラボ)らのグループは, 100GHzにお ける光DMUXの実験を行った $(\mathrm{CTuW1})$. クロック光パル ス $(12.5 \mathrm{GHz})$ とデータ光パルス $(100 \mathrm{GHz})$ を, 半導体光増幅 器(SOA) 中での非線形干渉 (4波混合)を利用する方式であ る.TOAD型とUNI型(Fig.38)の2種類について実験を行っ

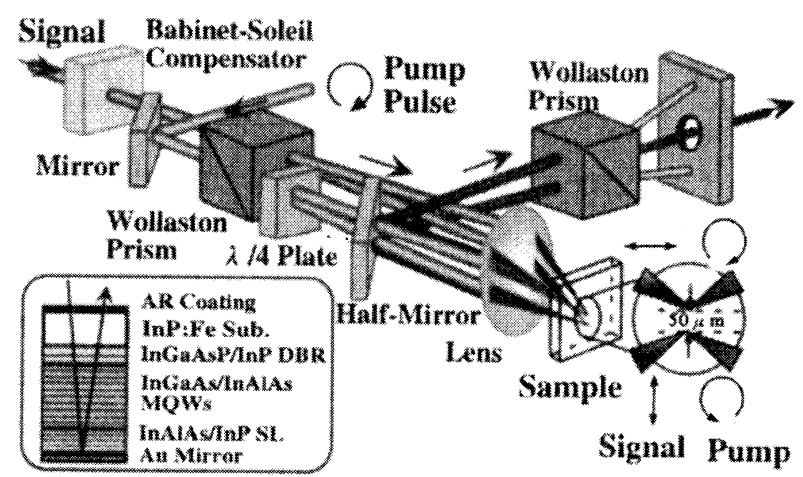

Fig.36 Experimental setup for enhancement of on/off ratios and polarization insensitivity using spin polarization. The inset represents a schematic structure of the device. (JThF4, R. Takahashi, et al.)

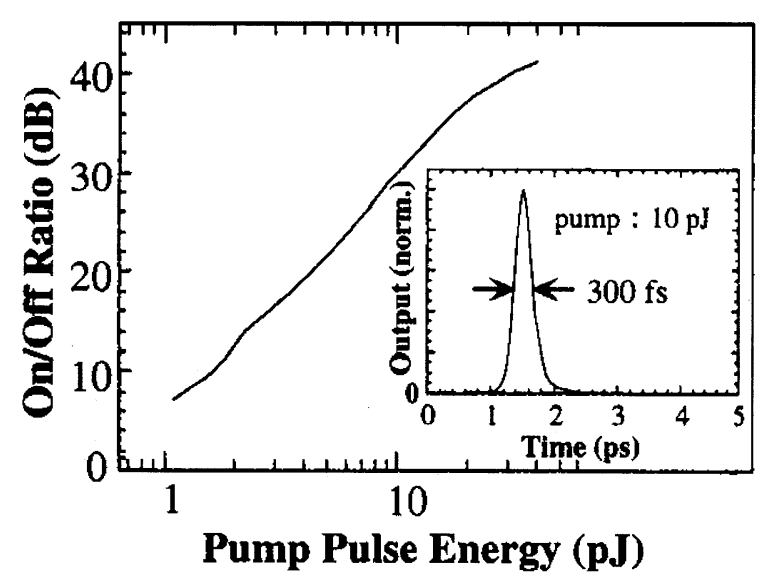

Fig.37 Experimental results of on/off ratios as a function of pump pulse energies. The inset represents a timeresolved switching characteristic. (JThF4, R. Takahashi, et al.)

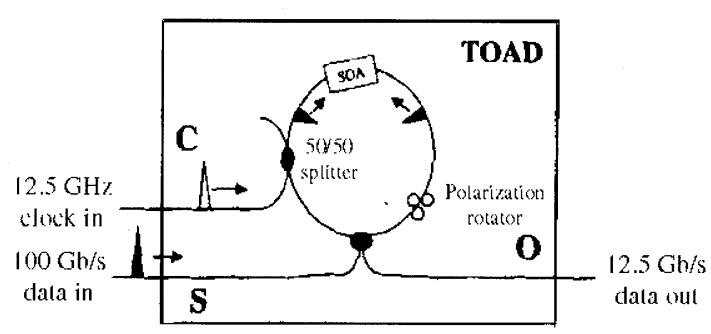

(a)

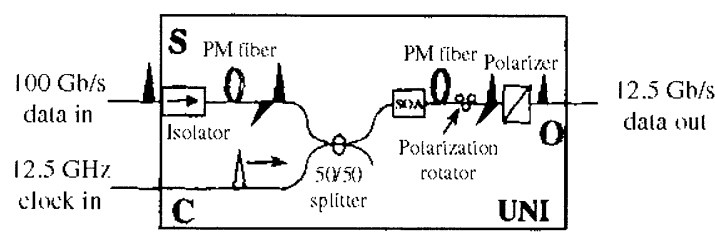

Fig.38 Schematic drawing of the (a) TOAD and (b) UNI. In these experiments the nonlinear switching elements are semiconductor optical amplifiers (SOA's). (CTuW1, K. H. Hall, et al.)

た. TOAD型では, クロック光パルスとデータ光パルスが SOAに逆方向から入射するのに対して, UNI型が同じ方向 ふらSOAに入射する。TOAD型では，丁沙計としてのSOA の長さにより100GHzにおける符号誤り率 (BER)が10-4以下 に下がらないのに対して, UNI型は100GHzにおいても実用 レベルであるBER10-10レベルを実現している(Fig.39).

\section{3 デバイス応用技術}

受光素子の高速化, 大出力化のためには, 暗電流の低減 と印加電圧の向上が望まれる. 更に, 伝送線路の高周波特 性の向上も受光器からの信号取り出しの観点からも重要 である. T. Itatani (電子技術総合研究所) らは, 光吸収層下 部に電流ブロック層を導入することにより,キャリアの実 効的な走行距離を低減して電子増倍現象を抑制すること により，暗電流の低減と素子耐圧 $20 \mathrm{~V}$ 以上を実現した (Fig.40). 素子のインパルス応答は4V印加時に800fs と高
TOAD

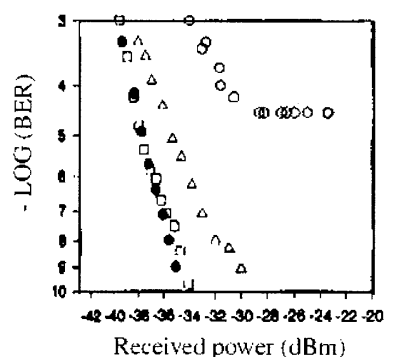

(a)

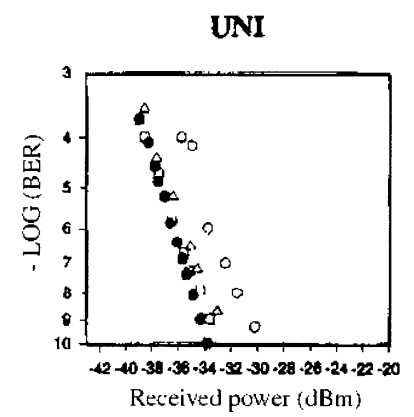

(b)
$12.5 \mathrm{~Gb} / \mathrm{s}$ baseline $\square 25 \mathrm{~Gb} / \mathrm{s}-\mathrm{to}-12.5 \mathrm{~Gb} / \mathrm{s}$ DEMUX $\therefore 50 \mathrm{~Gb} / \mathrm{s}-10-12.5 \mathrm{~Gb} / \mathrm{s} \mathrm{DEMUX}$ $100 \mathrm{~Gb} / \mathrm{s}-10-12.5 \mathrm{~Gb} / \mathrm{s}$ DEMUX

Fig.39 Experimental results of the switching operation. The plots show the $12.5 \mathrm{~Gb} / \mathrm{s}$ baseline (solid circles) as well as the results of demultiplexing a $12.5 \mathrm{~Gb} / \mathrm{s}$ data stream from a $25 \mathrm{~Gb} / \mathrm{s}$ data stream (squares), a $50 \mathrm{~Gb} / \mathrm{s}$ stream (triangles) and a $100 \mathrm{~Gb} / \mathrm{s}$ stream (hexagons). (CTuW1, K. H. Hall, et al.) 


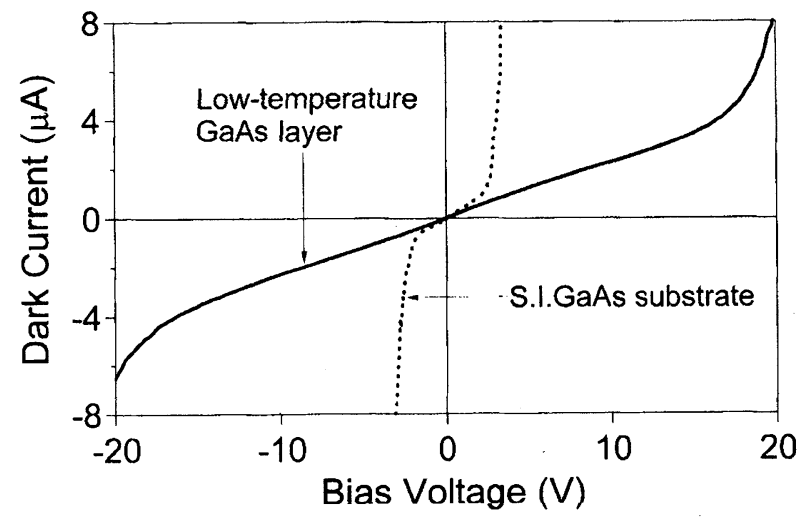

Fig.40 IV characteristics of the photoconductive switch. (CTuL2, T. Itatani, et al.)

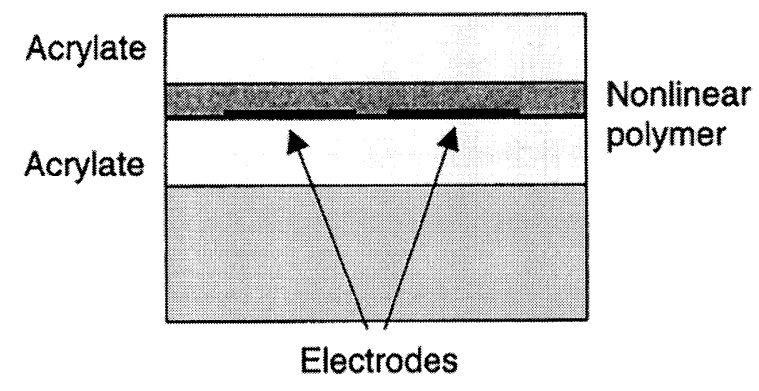

Fig.41 Schematic drawing of the device. A coplanar stripline transmission line is embedded in a multilayer polymer structure. The acrylate layers are used to minimize radiation losses. (CTuL1, A. Nahata, et al.)

速応答を実現している．A. Nahata(Allied Signal Inc.)らの グループは，放射損失を抑えるために，有機材料である

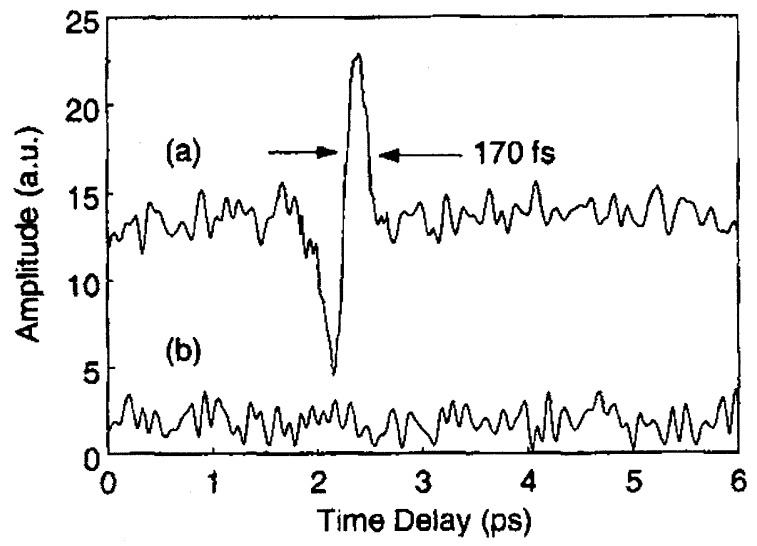

Fig.42 Temporal waveform observed with the excitation beam (a) centered between the transmission line and (b) $25 \mu \mathrm{m}$ outside of the transmission line structure. The distance from the generation to sampling points is $\sim 125 \mu \mathrm{m}$. The waveforms are offset from the orgin for clarity. (CTuL1, A. Nahata, et al.)

Acrylateで挟んだ導波路を作製し(Fig.41)，そのインパルス 応答をEOサンプリング法により測定した $(\mathrm{CtuL} 1) .125 \mu \mathrm{m}$ 伝搬した点におけるインパルス幅は170fsと非常に短いも のであり (Fig.42), 放射損失の抑制が高周波伝送線路の広 帯域化に有効であることを示した.M. Nagel(RWTH, Aachen)らのグループは, EOサンプリング法を用いてミリ 波ストップバンドフィルターの評価を行った(CTuL4)。電 界の空間分布の測定は,これまでの純電気的な方法では困 難な事から, EOサンプリング法が, ミリ波・マイクロ波領 域でのデバイス評価・設計支援ツールとして今後応用さ れることが期待される.

(板谷 太郎) 